\title{
Discovery of Inhibitors of Insulin-Regulated Aminopeptidase as Cognitive Enhancers
}

\author{
Hanna Andersson ${ }^{1}$ and Mathias Hallberg ${ }^{2}$ \\ ${ }^{1}$ Division of Organic Pharmaceutical Chemistry, Department of Medicinal Chemistry, BMC, Uppsala University, P.O. Box 574, \\ 75123 Uppsala, Sweden \\ ${ }^{2}$ Division of Biological Research on Drug Dependence, Department of Pharmaceutical Biosciences, BMC, Uppsala University, \\ P.O. Box 591, 75124 Uppsala, Sweden
}

Correspondence should be addressed to Mathias Hallberg, mathias.hallberg@farmbio.uu.se

Received 9 September 2012; Accepted 19 October 2012

Academic Editor: Patrick Vanderheyden

Copyright $\odot 2012 \mathrm{H}$. Andersson and M. Hallberg. This is an open access article distributed under the Creative Commons Attribution License, which permits unrestricted use, distribution, and reproduction in any medium, provided the original work is properly cited.

\begin{abstract}
The hexapeptide angiotensin IV (Ang IV) is a metabolite of angiotensin II (Ang II) and plays a central role in the brain. It was reported more than two decades ago that intracerebroventricular injection of Ang IV improved memory and learning in the rat. Several hypotheses have been put forward to explain the positive effects of Ang IV and related analogues on cognition. It has been proposed that the insulin-regulated aminopeptidase (IRAP) is the main target of Ang IV. This paper discusses progress in the discovery of inhibitors of IRAP as potential enhancers of cognitive functions. Very potent inhibitors of the protease have been synthesised, but pharmacokinetic issues (including problems associated with crossing the blood-brain barrier) remain to be solved. The paper also briefly presents an overview of the status in the discovery of inhibitors of ACE and renin, and of AT1R antagonists and AT2R agonists, in order to enable other discovery processes within the RAS system to be compared. The paper focuses on the relationship between binding affinities/inhibition capacity and the structures of the ligands that interact with the target proteins.
\end{abstract}

\section{Introduction}

Neuropeptides participate in the transmission or modulation of signals in the central nervous system (CNS) [1]. Hence, these peptides are engaged in neurological functions that include those related to cognition and memory, mood, the experience of pain, stress, reaction to reward, control of the intake of food, and neuroendocrinological regulation. The physiological action of neuropeptides is terminated by proteolytic degradation, and this is most often mediated by extracellular proteases anchored in the cell membrane. In this respect, neuropeptides differ from classic transmitters. Limited hydrolysis of neuroactive peptides may lead to the fragments being formed with either similar or very different biological activities [2]. The conversion of angiotensin II (Ang II) to angiotensin IV (Ang IV) is a good example of the latter. This type of biotransformation results from the action of more or less specific endoproteases. Several proteases that are capable of releasing bioactive fragments from their substrates have been identified in various CNS tissues [3, 4].

We discuss in this paper the renin-angiotensin system (RAS) and describe briefly how the two proteases, the angiotensin converting enzyme (ACE) and renin, have served and continue to serve as drug targets. We discuss briefly the two major receptors of the parent peptide angiotensin II, AT1R and AT2R, and we describe related antagonists and agonists to these receptors. Finally, we direct our focus to the hexapeptide Ang IV, which plays a central role in the brain. It has been suggested that the insulin-regulated aminopeptidase (IRAP) is the major target for Ang IV in the brain, and we therefore discuss in more detail recent progress in the discovery of inhibitors of IRAP. This paper concentrates on the molecular structures of the ligands that interact with the target proteins. 


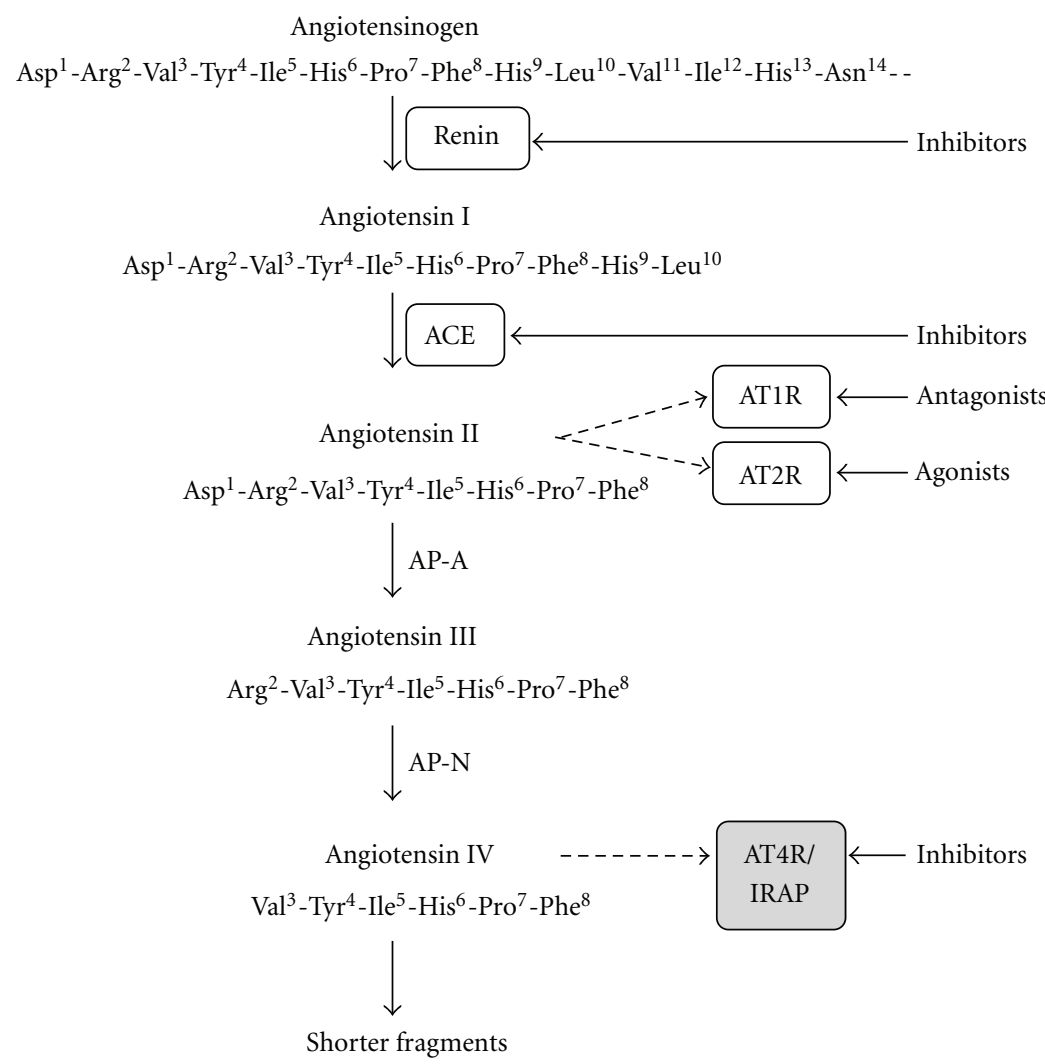

FIGURE 1: A part of the renin-angiotensin system (RAS), including selected degradation products and drug targets.

\section{Proteolytic Processing}

Angiotensin II (Ang II) is formed from angiotensin I (Ang I), which is an essentially inactive peptide derived from circulating and tissue angiotensinogen (Figure 1). The aspartyl protease renin liberates Ang I from angiotensinogen. The proteolytic cleavage of angiotensin I to produce Ang II is mediated mainly by the metalloproteinase ACE, an established target for drug therapy. Enzymatic cleavage by chymase, carboxypeptidase, catepsin $\mathrm{G}$ or tonin are alternative routes by which Ang II can be produced [5]. As in the cases of the tachykinins and the opioid peptides, metabolism of Ang II results in the formation of several fragments with biological activities that differ from those of the parent peptides. Proteolytic cleavage by glutamyl aminopeptidase A (AP-A) and membrane alanyl aminopeptidase $\mathrm{N}$ (AP-N), for example, results in the sequential removal of single amino acid residues from the $\mathrm{N}$-terminal end of the peptide, to form Ang III (Ang II(2-8)) and Ang IV (Ang II(3-8)), respectively [6]. These peptides are important neuropeptide fragments in the CNS [7-10]. Ang IV plays a particularly important role, and its mechanism of action is distinct [11-14]. It is noteworthy that Ang IV can be formed by the action of aminopeptidases on Ang I before it is converted to Ang II [15]. A previously unknown human Ang II-related peptide, denoted Ang A, has recently been discovered [16]. This peptide, $\left(\mathrm{Ala}^{1}\right)$-Ang II, is not a product of proteolysis but is derived from decarboxylation of the aspartic acid residue of Ang II [16]. It acts as a full agonist with properties that are similar to those of Ang II [17].

Chymotrypsin and dipeptidyl carboxypeptidase can further process Ang IV and the fragment Ang (3-7) to form inactive fragments and amino acid residues [18-23]. Ang (37) is formed from Ang IV by carboxypeptidase P (Carb-P) and propyl oligopeptidase (PO) cleavage. Chymotrypsin can hydrolyse bonds to Val, Tyr, and Ile, and this is an important property to consider when designing metabolically stable Ang IV analogues and Ang IV peptide mimetics. Furthermore, Ang II can be converted to the bioactive Ang (1-7) by the proteolytic removal of the C-terminal phenylalanine by Carb-P [12], the action of the monopeptidase ACE2 [24], and by ACE cleavage of the Phe-His from Ang (1-9) [25].

Figure 1 shows selected degradation products and five major drug targets. There are several other potential targets for drugs in the RAS, such as the Ang (1-7)/Mas receptor $[26,27]$ and the aminopeptidase A (AP-A), but these will not be discussed here (for a recent paper, see [28]). Neither will antagonists to AT2R as potential future drugs be discussed. This review will focus on the discovery of IRAP inhibitors.

\section{Inhibitors of Angiotensin Converting Enzyme and Renin}

Angiotensin II (Asp-Arg-Val-Tyr-Ile-His-Pro-Phe) is an important modulator of cardiovascular function and exerts a pronounced hypertensive effect. Forty years ago, it was 
discovered that minor modifications of the amino acid residue sequence of Ang II, such as the replacement of the phenylalanine residue at the $\mathrm{C}$-terminal by a residue with an aliphatic side chain, created peptides that block the action of Ang II. Two such peptides, saralasin (( $\left.\mathrm{Sar}^{1}, \mathrm{Ala}^{8}\right)$-Ang II) and sarile (( Sar $^{1}$, Ile $\left.^{8}\right)$-Ang II $)$, in which the $\mathrm{N}$-terminal sarcosine residue enhances the effect, were evaluated in clinical trials $[29,30]$. However, due to the peptidic character neither saralasin, approved by FDA for limited applications, nor the more potent sarile found long term use in clinic [3133]. They did, however, become important research tools and clinical observations from treatment with these two peptides confirmed that the RAS is a very relevant target for drug intervention. Hence, the two major proteases, renin and ACE, that are responsible for the degradation of the precursor protein angiotensinogen to the effector peptide Ang II, became attractive drug targets (Figure 1).

ACE inhibitors were subsequently disclosed [34, 35]. The design of the first ACE inhibitor took advantage of the similarity of ACE to the metalloproteinase carboxypeptidase A, which is inhibited by 2-benzyl succinic acid. It was also known that isolated peptides from extracts of venom from the Brazilian pit viper Bothrops jararaca have an antihypertensive effect, inhibiting the conversion of Ang I to Ang II. These two insights allowed the elegant and very rapid discovery of the zinc-binding thiol compound captopril, which entered the market in 1978. The nanopeptide (PyrTrp-Pro-Arg-Pro-Gln-Ile-Pro-Pro), known as "teprotide," had the highest in vivo potency among the venom peptides. It contains a proline residue at the C-terminal that is retained in captopril (Figure 2) [36]. Attempts to improve metabolic stability and to minimize the principal side effects of captopril, rashes and loss of taste, that it was hypothesized that the thiol group was responsible for, led to the once daily prodrug enalapril (Figure 2) that entered the market in 1985 $[37,38]$. In enalapril, the thiol group had been replaced by a zinc-coordinating carboxyl group. The high-resolution Xray crystal structure of enalapril (after liberation of the free carboxyl group from the prodrug) is now available [39] and shows that the N-terminal carboxyl group interacts with the catalytic zinc ion at the active site of ACE. The 3D structure of the membrane-bound ACE, however, was not known when the first ACE inhibitors were designed. Subsequently there was a large number of ACE inhibitors introduced, for example, ramipril, quinapril, perindopril, lisinopril, and benazepril, that today are extensively used in clinic [40].

Attempts to inhibit the other major protease involved in the proteolytic processing, the aspartyl protease renin, continued for decades, but it was not until 2007 that the first such inhibitor, aliskiren (Figure 3), reached the market [4143]. The development of renin inhibitors was often hampered by the peptidic character of the potential inhibitors being studied, leading as it did to limited metabolic stability, poor absorption, and, as a consequence of this, low oral bioavailability. It was, furthermore, difficult to predict effects in humans from results obtained in animal models. The compounds were transition-state analogues, in which the peptide bond to be cleaved had been substituted by a group that mimicked the transition state. The design of the<smiles>C[C@H](CS)C(=O)N1CCC[C@H]1C(=O)O</smiles>

Captopril

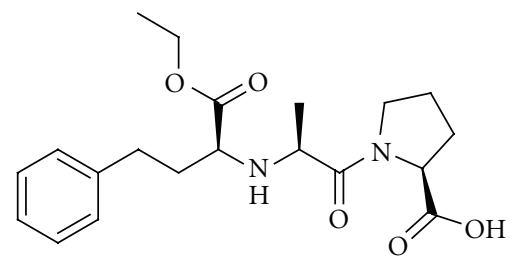

Enalapril

FIGURE 2: Captopril and enalapril, inhibitors of the angiotensin converting enzyme (ACE).

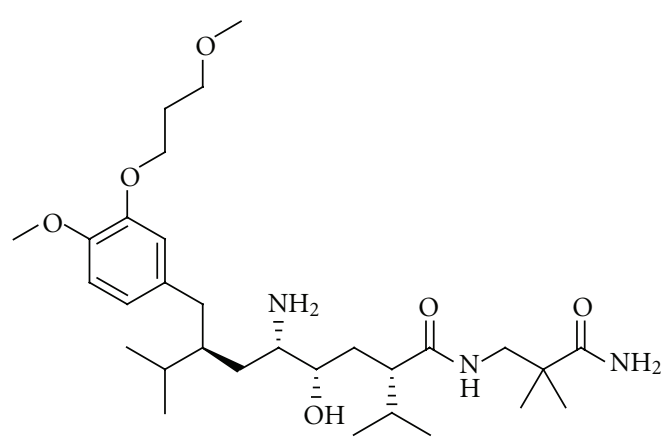

Aliskiren

FIGURE 3: The structure of the renin inhibitor aliskiren.

transition-state analogue aliskiren was aided by modelling and the availability of X-ray structures [44]. Experience gained during the renin inhibitor programmes benefited greatly programmes to discover HIV protease inhibitors, which were, in fact, on the market ten years before aliskiren. Significant progress has recently been made in identifying new potent non-peptide "direct renin inhibitors", but no such inhibitors have progressed to late stage development.

\section{Angiotensin II AT1 Receptor Antagonists and AT2 Receptor Agonists}

The first angiotensin receptor blocker (ARB) to be used in the clinic, the peptide saralasin, was not orally active and its duration of action was very short. Clinical results obtained with saralasin, however, demonstrated clearly that the Ang II receptor was a suitable target for drugs. The first non-peptide $\mathrm{ARB}$, losartan (Figure 4), was introduced onto the market in 1995. Losartan is characterized by the tetrazole moiety, which serves as a carboxylate bioisostere, at the biphenyl unit and by the readily oxidized hydroxymethyl group. Losartan 


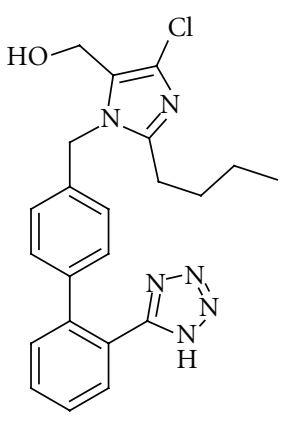

Losartan

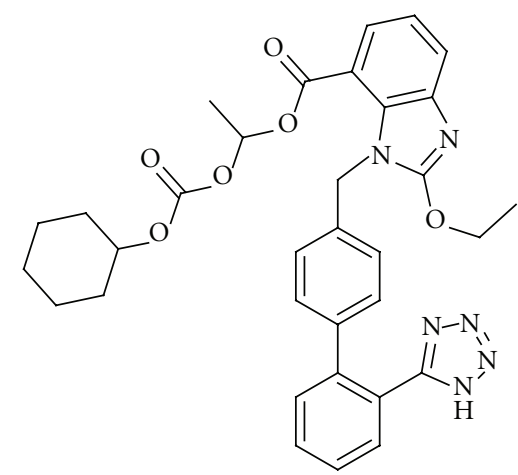

Candesartan cilexetil

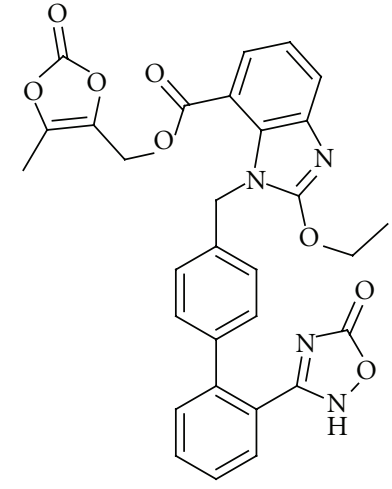

Azilsartan medoxomil

FIgURE 4: Three examples of Ang II AT1 receptor blockers (ARBs).

is converted in vivo by oxidation of the hydroxymethyl group to the more potent carboxylic acid metabolite. For a review on the discovery of angiotensin receptor blockers, see [45]. Several other AT1R antagonists are now in clinical use, for example, eprosartan, olmesartan, telmisartan, valsartan, and candesartan. The latter is administered as a prodrug, candesartan cilexetil (Figure 4). This liberates candesartan, which binds strongly to the AT1 receptor [46, 47]. It is believed that an optimal clinical effect of these drugs, known collectively as "sartans," requires high levels of target occupancy $[48,49]$. It should be mentioned in this context that an increasing number of examples in the literature suggest that the in vivo duration of drug action of AT1R blockers, for example, depends not only on macroscopic pharmacokinetic properties such as plasma half-life and the time needed to equilibrate between the plasma and the effect compartments, but also on long-lasting target binding and rebinding [50-52]. The prodrug azilsartan medoxomil (Figure 4), which has a less common carboxylic acid bioisostere attached to the biphenyl scaffold, was approved in 2011 and is the latest member of the ARB group [5355]. It is well established that AT1R antagonists are at least as effective as ACE inhibitors, $\beta$-blockers, and calcium channel antagonists in reducing cardiovascular morbidity and mortality [56, 57]. Furthermore, it is reported that losartan [58] and candesartan [59-61] have positive effects on cognition in elderly patients. Interestingly, TRV120023 representing a $\beta$-arrestin-biased AT1R ligand has cardioprotective and functional properties in vivo which are distinct from losartan. It has been suggest that this novel class of drugs that is $G$ protein independent but $\beta$-arrestin selective may provide an advantage over conventional ARBs by supporting cardiac function and reducing cellular injury during acute cardiac injury $[62,63]$. Anyhow, efforts to develop new and better chemical entities that block the AT1 receptor are limited. There is strong competition in this research field, which may partly explain this decision, but efforts to develop single compounds that can block both the AT1R and the receptor of the very potent vasoconstrictor endothelin A are in progress [64]. Furthermore, dual antagonism of AT1R and neutral endopeptidase inhibition has recently attracted interest. Clinical results from the dual inhibitor LCZ696, now in phases II-III, are promising [65].

Recently, the AT2 receptor has emerged as a new target for drug therapy [66-68]. The AT2 receptor is abundant in fetal tissues but in adults this $G$ protein-coupled receptor remains abundant only in certain tissues such as vascular endothelium [69] and brain areas $[70,71]$. The AT2 receptor is present in higher density in distinct regions of the brain and it has been suggested that it is involved in growth development and exploratory behaviour [72, 73]. It is expressed in the locus coeruleus, ventral and dorsal parts of lateral septum, the superior colliculus, and subthalamic nucleus, in the nuclei of many cells of the thalamus, and in nuclei in cells of the inferior olive. Both the AT1 and AT2 receptors are expressed in the cingulate cortex, the molecular layer of the cerebellar cortex, the superior colliculus and paraventricular nuclei [70, 74-76]. AT2R RNA and the receptor protein have recently been identified in the substantia nigra pars compacta [77] and in the hippocampus $[78,79]$. Thus, the receptor is present in the adult in areas associated with control and learning of motor activity, sensory areas, and selected structures of the limbic system [80]. It has been suggested that modulation of AT2R signalling can improve cognitive performance in persons with Alzheimer's disease (AD) not only through the action of an AT2R agonist on blood flow/brain microcirculation but also through its more specific effects on neurons [81]. Activation of the AT2 receptor affects neuronal cell differentiation and nerve regeneration [82-84]. Interestingly, several peripheral effects that are mediated through the AT2 receptor oppose other effects that are mediated through the AT1 receptor, suggesting that a similar balance may exist in the CNS $[85,86]$. It is worth noting that the AT2 receptor is re-expressed in some disease conditions such as heart failure, renal failure, myocardial infarction, hypertension, and some brain disorders [71, 87-92]. The AT2R mediates vasodilatory, antiproliferative and anti-inflammatory effects [93].

Several potent drug-like and selective AT2R agonists have been disclosed [94-96]. The first of these receptor-selective agonists, M024 or “compound 21" (M024/C21, Figure 5), 


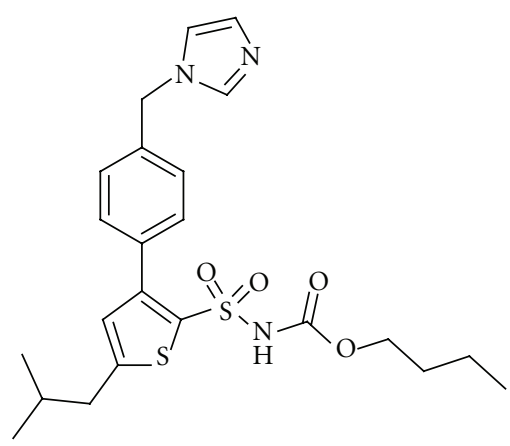

M024/C21

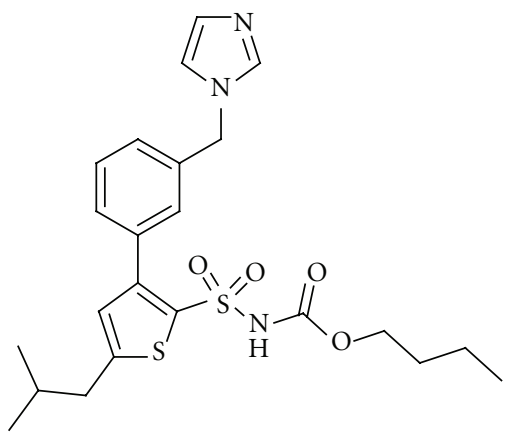

M132/C38

FIgURE 5: The structures of the selective AT2 receptor agonist M024/C21 and the structurally similar M132/C38, which acts as an AT2 receptor antagonist.

was first reported in 2004, and has been extensively studied since then [94]. It possesses a sulfonyl carbamate entity as a metabolically stable carboxylic acid isostere and exhibits a striking structural similarity to several AT1R antagonists. Compound M024/C21, developed through a series of modifications to the non-selective AT1R agonist L-162,313 [97], stimulates neurite outgrowth in neuronal cells (which express only AT2R) [94] through the sustained activation of p42/p44 mapk. It decreases dopamine synthesis in the rat striatum, and some results suggest that the AT1 and AT2 receptors in the striatum exert opposite effects on dopamine synthesis, rather than dopamine release [98]. The compound enhances cognitive functions in mice [81,99]. It improves myocardial function independently of blood pressure after myocardial infarction in normotensive Wistar rats [100] and has a pronounced anti-inflammatory effect [101]. M024/C21 gives improved vascular stiffness and lower collagen concentrations in the aorta and myocardium of stroke-prone spontaneously hypertensive rats [102]. It was recently suggested that the combination of M024/C21 with antihypertensive treatment might lead to vasculoprotective effects even beyond the blood-pressure-reducing effect [66, $103]$.

It is expected that bioavailability in the brain of the drug-like M024/C21 will be low [104]. This is expected to be the case also for M132/C38 (Figure 5), a selective AT2R antagonist with a very similar structure as M024/C21.
Nevertheless, this AT2R agonist/antagonist pair, in which the two compounds possess similar pharmacokinetics, should be an important and useful tool in studying the RAS. Furthermore, these molecules may serve as a starting point in medicinal chemistry programmes aimed at discovering molecules that are active as AT2R agonists in the brain after oral administration. No selective AT2R agonists have still entered phase I clinical trial. On the contrary, EMA401, a lipophilic structural analogue of the commonly used research tool, the AT2 receptor antagonist PD123319 is in clinical trials. This antagonist is developed for neuropathic pain [105].

\section{Inhibitors of Insulin-Regulated Aminopeptidase}

In 1988, Braszko et al. reported that intracerebroventricular (i.c.v.) injection of the Ang II metabolite Ang IV (Val-TyrIle-His-Pro-Phe, Figure 6) improved memory and learning in the rat [106]. They showed that Ang IV affects motor activity, the performance of passive avoidance, and a conditioned avoidance response. Various animal models were subsequently investigated, and results were obtained for Barnes maze, swim mazes, and radial arm mazes [8, 14, 107-110]. Not only Ang IV but also related analogues were studied, such as the endogenous LVV-hemorphin7 (Leu-Val-Val-Tyr-Pro-Trp-Thr-Glu-Arg-Phe), which has structural similarities to Ang IV at the N-terminal part of the peptide, in that it has a tyrosine residue attached to lipophilic amino acid residues [111]. LVV-hemorphin-7 is a powerful promoter of memory retention and retrieval in rats [107]. The observation that Ang IV improves processes related to memory and learning has attracted considerable interest in recent years. Excellent reviews have been published describing the role of Ang IV in the brain [112-114]. Efficient new chemical entities for the treatment of the cognitive decline associated with Alzheimer's disease, brain trauma, and cerebral ischemia are needed since the clinical studies of the cholinesterase inhibitors and NMDA antagonists used today have been mostly disappointing [115118]. Thus, new improved enhancers of cognitive functions are desired and the receptor(s) involved in the beneficial effects of Ang IV has emerged as a relevant new target for drug intervention.

A specific binding site for Ang IV was identified in 1992, and was later named the AT4 receptor [119-121]. Harding et al. found high densities of binding sites in areas of the brain associated with cognitive, sensory and motor functions, including the hippocampus [120].

5.1. Ligands with Affinity to the AT4 Receptor. Shortly after the discovery of the binding sites, systematic structureactivity relationship studies (SAR) were commenced by Wright and Harding and it became clear that the ValTyr-Ile tripeptide motif in the N-terminal part of Ang IV was of critical importance for binding affinity [122]. This conclusion relied on classic glycine and d-amino acid scans and various other alterations of the amino acid residues of 


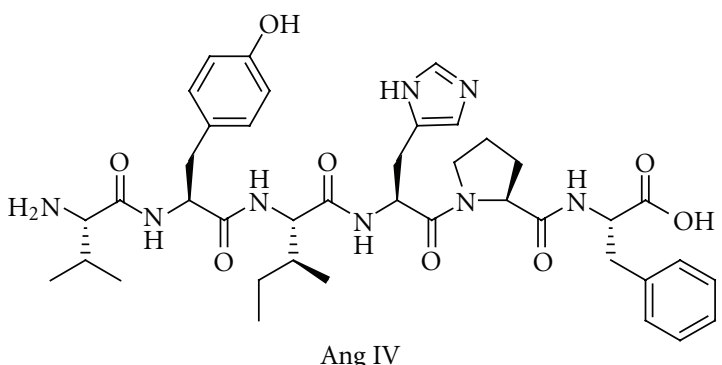<smiles>CCCC[C@H](N)CN[C@@H](Cc1ccc(O)cc1)C(=O)N[C@H](C(=O)N[C@@H](Cc1cnc[nH]1)C(=O)N1CCCC1C(=O)N[C@@H](Cc1ccccc1)C(=O)O)[C@@H](C)CC</smiles><smiles>CC(C)[C@H](N)CN[C@H](Cc1ccc(O)cc1)C(=O)N[C@H](CN[C@@H](Cc1cnc[nH]1)C(=O)N1CCC[C@H]1C(=O)N[C@@H](Cc1ccccc1)C(=O)O)C(C)C</smiles>

Divalinal-Ang IV<smiles>CCCC[C@H](N)C(=O)N[C@@H](Cc1ccc(O)cc1)C(=O)N[C@H](CN[C@H](Cc1cnc[nH]1)C(=O)N1CCC[C@H]1C(=O)N[C@@H](Cc1ccccc1)C(=O)O)[C@@H](C)CC</smiles>

Norleual

Figure 6: Ang IV and three hexapeptide analogues that incorporate one or two reduced peptide bonds $\left(\Psi\left[\mathrm{CH}_{2} \mathrm{NH}\right]\right)$ as peptide bond bioisostere.

Ang IV [123, 124]. Hydrophobic residues at position one, and norleucine in particular, rendered very high binding affinities, while substitution of the N-terminal amine by acetylation or methylation lead to low affinity ligands. Thus, a residue with straight aliphatic side-chain combined with a primary amine function was found to be preferred in the N-terminal. The C-terminal part, on the other hand, could be altered without affecting the binding affinity dramatically. However, truncations with the exception of removal of the C-terminal phenylalanine residue were found to be unproductive [122].

The hexapeptide Ang IV and its peptide analogues are prone to undergo proteolytic cleavage but a significant improvement of the metabolic stability could be achieved by reduction of the peptide bond between $\mathrm{Val}^{1}$ and $\mathrm{Tyr}^{2}$ of Ang IV with most of the affinity retained. Analogue 1 (Figure 6) constitute another such example, encompassing a reduced peptide bond $\left(\Psi\left[\mathrm{CH}_{2} \mathrm{NH}\right]\right)$ between residues one and two and thus two amine sites that can be protonated [123]. Divalinal-Ang IV and norleual (Figure 6) are two other pseudopeptides comprising reduced peptide bonds that were studied in some detail and served as important research tools $[125,126]$.

Kobori et al. at Taisho Pharmaceuticals filed patent applications in the late 1990s that disclosed a series of compounds that bind strongly to guinea pig hippocampus membranes $[127,128]$. They had deduced this from competitive experiments with radiolabeled $\left[{ }^{125} \mathrm{I}\right]$ Ang IV. The compounds with the highest binding affinity are characterized by a straight fourcarbon chain at position one and a reduced amide bond $\left(\Psi\left[\mathrm{CH}_{2} \mathrm{NH}\right]\right)$ between residues one and two. These highaffinity compounds have also a styrene moiety that replaces His-Pro-Phe in Ang IV, (compound 2 and quinoline 3 in Figure 7) and they have IC50 values lower than $1 \mathrm{nM}$. Ligand 4 in Figure 7 has three basic amino groups and was produced by reducing the amide bond between residues two and three in compound 2. This compound has a binding affinity for hippocampus membranes that is 40 times lower than that of compound 2. A ligand essentially devoid of affinity was obtained by maintaining the peptide bond between residues one and two intact and reducing the bond $\left(\Psi\left[\mathrm{CH}_{2} \mathrm{NH}\right]\right)$ between residues two and three. Furthermore, reduction of the trans double bond at the C-terminal leads to considerably lower affinities. The potent ligands synthesized by Kobori et al. have to the best of our knowledge not been evaluated as IRAP inhibitors.

5.2. Inhibitors of Insulin-Regulated Aminopeptidase (IRAP). A receptor for Ang IV was purified from bovine adrenal membranes in 2001. This AT4 receptor was identified as the insulin-regulated aminopeptidase (IRAP) [129]. The $\mathrm{IRAP}_{\mathrm{ATT}}$ receptor has attracted considerable interest in recent years as a potential target for pharmaceuticals aimed for the treatment of cognitive disorders [112, 130-133]. IRAP is a single-spanning transmembrane zinc-metallopeptidase that belongs to the M1 family of aminopeptidases. IRAP has been identified as cystinyl aminopeptidase (CAP, EC 3.4.11.3), placental leucine aminopeptidase (P-LAP, soluble human homologue), oxytocinase, gp160, or vp165 [134137]. The insulin-regulated aminopeptidase has been cloned and characterized in adipocytes in vesicles that contain the insulin-regulated glucose transporter GLUT4 [138]. IRAP contains three domains [136, 139-141]: an intracellular region that is involved in intracellular localization and redistribution, a hydrophobic transmembrane segment, and an extracellular region that contains the catalytic site. The M1 family shares a consensus His-Glu-Xaa-Xaa-His-(Xaa) ${ }_{18}$ Glu zinc-binding motif that is essential for enzymatic activity, and a Gly-Xaa-Met-Glu-Asn (Xaa = Ala in IRAP) 
<smiles>CCCC[C@H](N)CN[C@@H](Cc1ccc(O)cc1)C(=O)N[C@H](/C=C/c1ccccc1)CC(C)C</smiles><smiles>CCCC[C@H](N)CN[C@@H](Cc1ccc(O)cc1)C(=O)N[C@H](/C=C/c1ccc2ccccc2n1)CC(C)C</smiles><smiles>CCCC[C@H](N)CN[C@H](CN[C@H](/C=C/c1ccccc1)Cc1ccc(O)cc1)CC(C)C</smiles>

4

Figure 7: Highaffinity Ang IV receptor binding analogues that incorporate one or two reduced peptide bonds $\left(\Psi\left[\mathrm{CH}_{2} \mathrm{NH}\right]\right)$ and a styrene moiety replacing the C-terminal tripeptide His-Pro-Phe of Ang IV.

exopeptidase motif. The zinc ion is coordinated to the two His residues, the second Glu residue, and a water molecule, which is anticipated to be activated by the other Glu residue during the hydrolytic step [142-144]. Mutational analyses have shown that the Gly-Ala-Met-Glu-Asn motif is important in the recognition of the N-terminal of both substrates and competitive inhibitors [139, 145, 146]. An important and characteristic property of the aminopeptidase is its ability to cleave the $\mathrm{N}$-terminal amino acid residue from several bioactive peptides in vitro, including Metenkephalin and Leu-enkephalin, dynorphin A, neurokinin A, cholecystokinin-8, somatostatin, oxytocin, and vasopressin [135, 147, 148].

Several hypotheses have been presented to explain the ability of Ang IV and its analogues to enhance cognitive

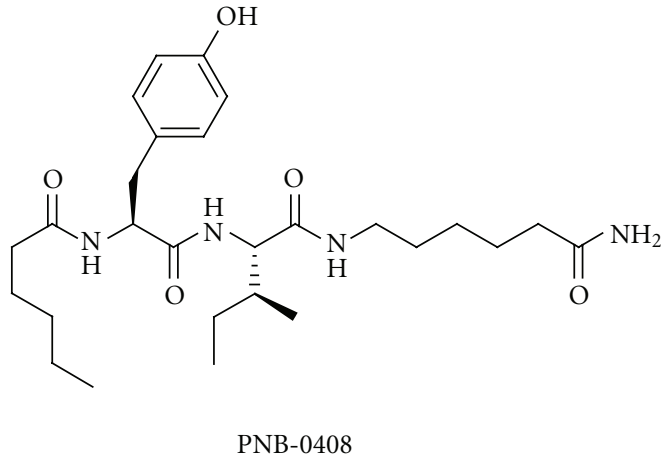

FIGURE 8: The structure of the compound PNB-0408, which crosses the blood-brain barrier.

functions $[25,149,150]$. One hypothesis concerns substrates such as vasopressin, somatostatin, and cholecystokinin, whose half-lives are prolonged when IRAP is inhibited by Ang IV, LVV-hemorphin-7 or analogous derivatives [151, 152]. These substrates improve parameters associated with cognition [153], and vasopressin and oxytocin are considered to be the main substrates of IRAP $[148,154]$. It was recently shown that somatostatin has an impact on memory processing through its action on the somatostatin receptor subtype 3 [155]. A second hypothesis proposes that IRAP acts as a classical receptor that transfers information across the cell membrane after receptor binding, while a third is that the Ang IV analogues prolong the localisation of IRAP and GLUT4 at the cell surface, and thereby modulate the uptake of glucose into neurons and other cells [112, $150,156,157]$. Furthermore, it has been proposed that the metallopeptidases in the same family as IRAP, such as aminopeptidase N (AP-N, EC 3.4.11.2), are targets [158]. Both Ang IV and LVV-hemorphin-7 inhibit AP-N activity [159]. Alternative macromolecular targets for Ang IV have been proposed, such as c-Met, a tyrosine kinase receptor that binds hepatocyte growth factor (HGF) and that is associated with memory and learning consolidation [160, 161]. Norleual (Figure 6) inhibits HGF-mediated effects at picomolar concentrations and blocks $\left[{ }^{125} \mathrm{I}\right] \mathrm{HGF}$ binding to c-Met.

The receptor or receptors that are involved in the positive identity identities of the effects of Ang IV and its analogues is still not clear, but both IRAP and c-Met are probably involved [114]. The availability of IRAP/Ang IV receptor ligands that are able to penetrate into the brain is important in order to obtain mechanistic insights. Wright and Harding have synthesised PNB-0408 (Nhexanoyl-Tyr-Ile- $\mathrm{N}^{\prime}$-(5-carbamoylpentyl)amide, Figure 8) and have shown that it crosses the blood-brain barrier and enhances cognitive activity $[133,162,163]$. This compound should be a very useful research tool. The activity profiles of this modified tripeptide and related analogues have now been established in several models of dementia [133].

Wright and Harding, and their group in USA, have been pioneers in identifying compounds that bind strongly to the 
<smiles>[R]C(=O)[C@H](NC(=O)[C@H](Cc1ccc(O)cc1)NC(=O)[C@@H](CN)C(C)C)[C@@H](C)CC</smiles>

$\mathrm{N}$-terminal part<smiles>CC[C@H](C)[C@H](NC(=O)C1(NC(=O)[C@@H](N)C(C)C)CCc2cc(O)ccc2C1)C(=O)[I-]</smiles>

5<smiles>CN[C@H](Cc1cnc[nH]1)C(=O)N1CCC[C@H]1C(=O)N[C@H](CC(=O)O)Cc1ccccc1</smiles>

AL-11<smiles>CC[C@H](C)[C@H](NC(=O)[C@H](Cc1c(C)cc(O)cc1C)NC(=O)[C@@H](N)C(C)C)C(=O)C(C)C</smiles>

6<smiles>CCN[C@H]1Cc2c([nH]c3ccccc23)CN(CC(=O)N[C@@H](Cc2ccccc2)C(=O)O)C1=O</smiles>

AL-40

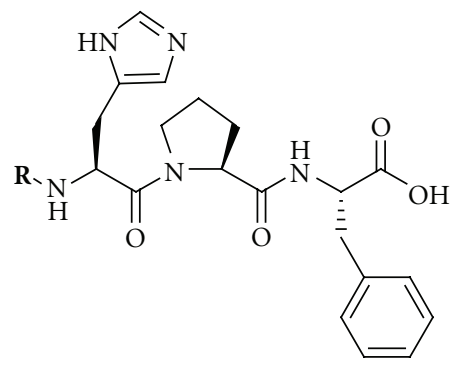

C-terminal part

FIgURE 9: Examples of recently identified IRAP inhibitors.

Ang IV receptor, as are also Kobori et al. in Japan. Several other research groups have devoted considerable efforts in recent years to developing small molecules that interact with the Ang IV receptor, for example, in Belgium, Sweden, and (in particular) in Australia. These latter three groups have focussed on making efficient inhibitors of IRAP, and they have used slightly different and complementary approaches. The major objectives have been to identify powerful, selective inhibitors that are metabolically stable, and that resist, in particular, degradation by IRAP itself and related peptidases. To make inhibitors with high bioavailability in brain after oral administration is a tremendous challenge.

Many of the ligands previously identified as high-affinity binders were found to inhibit IRAP [111, 164]. Metal chelators (such as EDTA and phenanthroline) had previously been routinely used in experiments that measured binding affinity. It now became important to determine the ability of ligands to inhibit the hydrolysis of synthetic substrates in the absence of metal chelators. Ligands had different potencies and frequently different rank orders in the IRAP assay in the absence of chelators. It was suggested that the differences were a result of the absence of zinc in the active site when metal chelators were present [159, 164-166]. Thus, it became obvious that chelators must be omitted to obtain physiologically relevant results [167]. Furthermore, the results illustrated also the importance of synthesising inhibitors that are metabolically stable and are not substrates of IRAP.

Lukaszuk et al. in Belgium have recently performed a $\beta$-homoamino acid scan of Ang IV [168]. Replacement of
$\mathrm{Val}^{1}$ by (R)- $\beta^{2} \mathrm{hVal}$ and replacement of $\mathrm{Phe} \mathrm{e}^{6}$ by $\beta^{3} \mathrm{hPhe}$ led to a metabolically stable and potent IRAP inhibitor, AL-11 (Figure 9). This has a high selectivity for IRAP over AP-N and the AT1 receptor. It has been reported that Ang IV affects blood pressure by a process that is mediated by the AT1 receptor [169]. The His ${ }^{4}$ and Pro $^{5}$ residues were subsequently replaced by other, conformationally constrained, residues [170]. Incorporating (R)- $\beta^{2} \mathrm{hVal}^{1}$ and $\mathrm{Aia}^{4}-\mathrm{Gly}^{5}$ gave a compound that is highly selective and stable and has a high inhibitory effect (AL-40, Figure 9) [168, 170]. Ang IV itself is only a weak inhibitor of the catalytic activity of IRAP, as has been shown by experiments with the metabolically stable tritiated Ang IV analogue $\left[{ }^{3} \mathrm{H}\right] \mathrm{AL}-11$, in combination with the selective AP-N inhibitor $7 \mathrm{~B}$ which is a phosphinic transition-state analogue [171] and in the absence of metal chelators. Adding metal chelators creates the apoform of IRAP [167, 172], and it is important to note that the active form and apoforms of IRAP react differently [173]. Hence, much of the previous results refer to binding to the apoenzyme rather than to the catalytically active enzyme [122-124, 174]. Ascher et al. have recently discussed the regulation of the peptidase activity of IRAP in detail [175].

The Belgian group also performed an extensive study that examined the roles of $\mathrm{Tyr}^{2}, \mathrm{Pro}^{5}$, and $\mathrm{Phe}^{6}$ in Ang IV by introducing conformational constraints at the different amino acid residues. The study confirmed that conformational constraints are important in obtaining selectivity. Replacing $\mathrm{Tyr}^{2}$ by any one of several conformationally constrained residues impairs the activity of the peptide, while modifications at the C-terminal are more acceptable. 
<smiles>CC[C@H](C)[C@H](NC(=O)c1cc(Cc2ccc(O)cc2)cc(NC(=O)[C@@H](N)C(C)C)c1)C(=O)N[C@@H](Cc1cnc[nH]1)C(=O)N1CCC[C@H]1C(=O)N[C@@H](Cc1ccccc1)C(=O)O</smiles><smiles>CC[C@H](C)[C@H](NC(=O)[C@H](Cc1ccc(O)cc1)NC(=O)[C@@H](N)C(C)C)C(=O)N[C@@H]1CSSC[C@H](NC(=O)[C@H]2CCCN2C(=O)O)C(=O)O1</smiles><smiles>CC[C@H](C)[C@H](NC(=O)[C@H](Cc1ccc(O)cc1)NC(=O)[C@@H](N)C(C)C)C(=O)NCc1ccccc1CC(=O)O</smiles>

9

Figure 10: The structures of the Ang IV peptidomimetics 7-9.<smiles>N[C@@H](CCSSCC[C@H](NC(=O)[C@@H](Cc1ccc(O)cc1)NC(=O)[C@@H](N)Cc1cnc[nH]1)C(=O)N1CCC[C@H]1C(=O)N[C@@H](Cc1ccccc1)C(=O)O)C(=O)NC(Cc1ccccc1)Cc1ccccc1</smiles>

10<smiles>N[C@@H](CNCc1ccccc1CC(=O)O)C(=O)N[C@@H](Cc1ccc(O)cc1)C(=O)N[C@@H](CCSSCC[C@H](N)Cc1ccccc1)C(=O)O</smiles>

11<smiles></smiles>

12

FIGURE 11: The structures of three IRAP inhibitors from a series of disulfide-cyclized Ang IV peptidomimetics. The ability to inhibit IRAP increases from 10 to $\mathbf{1 2}$. Both 11 and $\mathbf{1 2}$ have 2000-fold selectivity for IRAP over AP-N.

Analogues 5 and 6 (Figure 9), for example, inhibit IRAP to a very low degree. This suggests that the orientation of the $\mathrm{Tyr}^{2}$ side chain is critical for activity [176].

Our approach in Sweden to obtain active inhibitors of IRAP has been based on an ambition to determine various bioactive conformations by introducing local steric constraints. We have also worked to create various secondary structures by side chain cyclizations. Incorporation of a 4hydroxydiphenylmethane scaffold as a substitute for $\mathrm{Tyr}^{2}$ as part of the attempts to create steric constraint, as in Compound 7 (Figure 10), is deleterious for activity. This result again suggested that position two is susceptible 


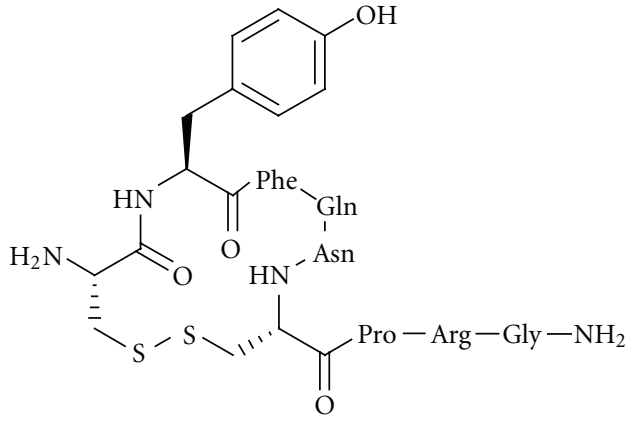

Vasopressin

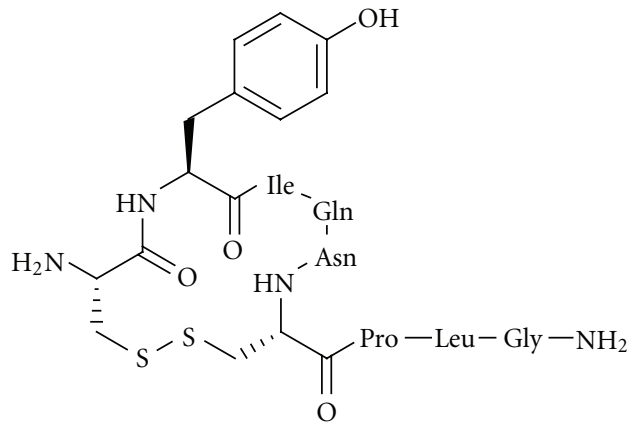

Oxytocin

FIGURE 12: The macrocyclic disulfides vasopressin and oxytocin are substrates of IRAP.<smiles>N[C@@H](CCCC/C=C/C[C@H](NC(=O)[C@H](Cc1ccc(O)cc1)NC(=O)[C@@H](N)CNCc1ccccc1CC(=O)O)C(=O)O)Cc1ccccc1</smiles>

13

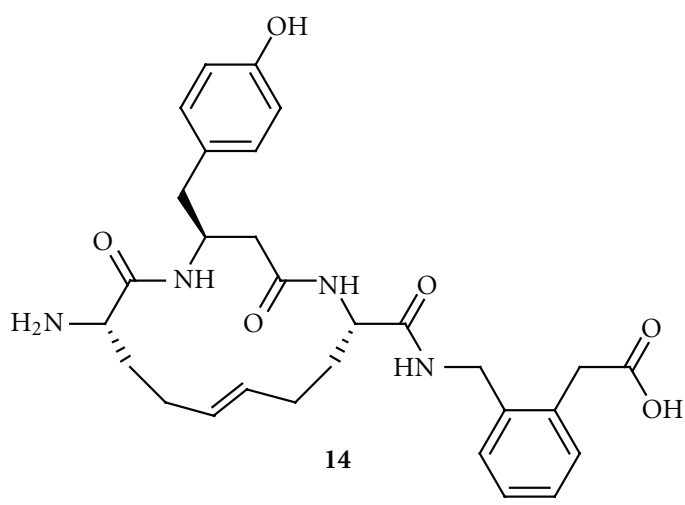

FIGURE 13: Macrocyclic Ang IV peptidomimetics that strongly inhibit IRAP. to structural manipulation [177]. A series of macrocyclizations was performed in order to obtain improved inhibitors and to better understand how Ang IV binds to IRAP [174, 178-180]. Cyclization of $\left[\mathrm{Cys}^{4}, \mathrm{Cys}^{6}\right]$ Ang IV to form an 11membered ring resulted in a compound $\left(8, K_{i}=26 \mathrm{nM}\right.$, Figure 10) that is more potent than Ang IV $\left(K_{i}=62 \mathrm{nM}\right)$ as an IRAP inhibitor. Previous conformational analyses of Ang II suggested that such a macrocyclic system would tend to adopt an inverse $\gamma$-turn $[181,182]$, and the replacement of His-Pro-Phe by a 2-(aminomethyl)phenylacetic acid moiety designed to mimic an inverse $\gamma$-turn resulted in compound 9 (Figure 10). This compound has a $K_{i}$ value of $44 \mathrm{nM}$ and a much simpler structure than previous candidates [171].

Cyclization of $\left[\mathrm{Cys}^{1}, \mathrm{Cys}^{3}\right]$ Ang IV gives an inactive inhibitor with an 11-membered ring system, while a compound with fair inhibitory potency and a 13-membered macrocycle is obtained using $\left[\mathrm{Hcy}^{1}, \mathrm{Hcy}^{3}\right]$ Ang IV $\left(\mathbf{1 0}, K_{i}=\right.$ $303 \mathrm{nM}$, Figure 11). The hybrid of $\mathbf{9}$ and $\mathbf{1 0}$ is a potent inhibitor (11, $K_{i}=23 \mathrm{nM}$, Figure 11), and, importantly, selective for IRAP over AP-N. Thus, it appears that that Ang IV adopts a $\gamma$-turn at the C-terminal when binding to IRAP, while an open, less well-defined turn conformation is present at the N-terminal. Further structural optimisation produced compound 12 (Figure 11), which has a $\beta^{3} \mathrm{hTyr}$ residue in a 13 -membered macrocycle. Its $K_{i}$ value is $3.3 \mathrm{nM}$. This compound is 20 times more potent than Ang IV and exhibit a 2000-fold selectivity for IRAP over AP-N [180]. Removal of the carboxyl group at the C-terminal gives less efficient inhibitors of IRAP. Hence, macrocyclizations by oxidative disulfide formations can provide very potent IRAP inhibitors.

Macrocyclizations, obtained by applying the metathesis reaction, are very attractive in efforts to make potent compounds with high oral bioavailability $[183,184]$. This observation and the knowledge that compounds such as vasopressin and oxytocin (Figure 12) are macrocyclic in the $\mathrm{N}$-terminal part and substrates of IRAP [148] prompted the synthesis of carba analogues. It was believed that these would be efficient IRAP inhibitors that were more metabolically stable.

A large series of macrocyclic compounds were prepared, of which the compounds labelled 13 and 14 (Figure 13) have the lowest $K_{i}$ values, $4.1 \mathrm{nM}$ and $1.8 \mathrm{nM}$, respectively [179]. These carba analogues are also the most metabolically stable analogues that were synthesized in the programme. In the absence of chelators, the binding affinity of the 14membered macrocyclic compounds to IRAP is 10 times higher than that of Ang IV. N-Methylation of the peptide bond between residues one and two reduces the activity, suggesting that the amide nitrogen and the $\mathrm{N}$-terminal primary amine nitrogen are coordinated to the zinc atom in the active site of the protease [179]. Incorporation of a methylene group adjacent to the $\mathrm{N}$-terminal amino group, as in AL-11 and AL-40 (Figure 9), and replacement of the C-terminal carboxyl group with bioisosteres seem to be the obvious next steps in efforts to improve the inhibitors. The amide bond between residues one and two, which is present in all of the macrocyclic inhibitors that have been reported, is the major target for IRAP. Thus, exchanging this bond 
<smiles>CCOC(=O)C1=C(NC(C)=O)Oc2cc(O)ccc2C1c1cccnc1</smiles>

HFI-419<smiles>CCOC(=O)C1=C(N)Oc2cc(O)ccc2C1c1cnc2ccccc2c1</smiles>

HFI-435<smiles>CCOC(=O)C1=C(NC(C)=O)Oc2cc(O)ccc2C1c1cnc2ccccc2c1</smiles>

HFI-437

FIGURE 14: Recently identified potent non-peptidic IRAP inhibitors with a benzopyran scaffold.

for a proteolytically inert $\mathrm{CH}_{2} \mathrm{NH}$ fragment may improve the properties. Such a $\mathrm{CH}_{2} \mathrm{NH}$ fragment should provide also a strong coordination to zinc.

The Australian group discovered a series of IRAP inhibitors based on a benzopyran system as scaffold. These drug-like compounds should be more metabolically stable than the peptidomimetics previously discussed [113]. While compounds 13 and 14 were produced through various modifications of pre-existing compounds, primarily macrocyclizations of Ang IV itself, inhibitors based on benzopyrans originate from a structurebased design process and virtual screening.

The 3D structure of IRAP is not known. Thunnissen et al. therefore used the structurally related human leukotriene $\mathrm{A}_{4}$ hydrolase [185], which also belongs to the M1 aminopeptidase family, in an in silico screening aimed at identifying potential inhibitors [186]. The process involved the in silico screening of 1.5 million commercially available compounds against a model structure homologous to IRAP, identification of hits, biological evaluation of hits, and optimisation of structures. Several potent drug-like benzopyrans were identified as IRAP inhibitors. Among those, the racemic pyridine derivative HFI-419, and the quinoline derivatives HFI-435 and HFI-437 (Figure 14), are selective for IRAP, with $K_{i}$ values of 420,360 , and $20 \mathrm{nM}$, respectively. The compounds bind with low affinity to structurally related enzymes, such as AP-N and leukotriene $\mathrm{A}_{4}$ hydrolase itself, despite the latter having been used in the homology modelling [186]. Computational docking suggests that the $S$-isomer is the preferred binding mode in all examples, and two alternate binding conformations for these structurally analogous inhibitors have been proposed [187].

The quinoline compounds HFI-435 and HFI-437 cannot adopt the same binding mode as the pyridinyl compound HFI-419 for steric reasons, but HFI-435 and HFI-437 seem to adopt binding modes that allow a stronger interaction with the zinc ion through coordination with the nitrogen atom in the quinoline heterocycle. It has been predicted that the quinoline compounds are more active than the pyridinyl compounds, partly due to a more favourable coordination to the zinc ion in IRAP. In addition, computational docking experiments have suggested that $\mathrm{Phe}^{544}$ of IRAP provides an important hydrophobic packing point at one side of the active site [187]. No comparative modelling has been carried out, but it is tempting to suggest that the $\mathrm{N}$-terminal of Ang IV, the macrocyclic compound $\mathbf{1 3}$ and the quinoline HIF-437 bind to IRAP as shown in Figure 15. The amide nitrogen (or the amide oxygen) and/or the $\mathrm{N}$-terminal nitrogen atom may interact with the zinc atom.

Albiston et al. demonstrated that i.c.v. administration of HFI-419 enhances memory in two memory paradigms. The performance of rats in a task involving spontaneous alternation of spatial working memory after administration of compound HFI-419 [186] was similar to the performance after administration of Ang IV and LVV-hemorphin-7 [14]. Results from in vivo experiments with this drug-like class of compounds strongly support the strategy of using IRAP as a target for cognitive enhancers. The benzopyran class of IRAP inhibitors provides promising leads for further development.

\section{Conclusions}

Experimental data from various animal models demonstrate that inhibitors of IRAP facilitate memory. The explanations to the beneficial effects on a biochemical level are not clear and many alternative hypotheses have been proposed. Further studies to elucidate the mechanism of action are needed. In this context, metabolically stable IRAP inhibitors, able to cross the blood-brain barrier and with fair bioavailability in brain should serve as important research tools. Such inhibitors could also provide new chemical entities and enhancers of cognition for future treatments of the memory loss associated with ageing and AD. All data with IRAP inhibitors available today were achieved after i.c.v. administration and new inhibitors with oral bioavailability are highly desirable. There are in brief two different approaches addressing the discovery of such inhibitors. One starts from Ang IV itself. After subsequent truncations and macrocyclizations, stabilizing favourable conformations, potent inhibitors could be obtained. However, these are still peptidic in character. The other approach originates from a virtual screening and the utility of a homology model 

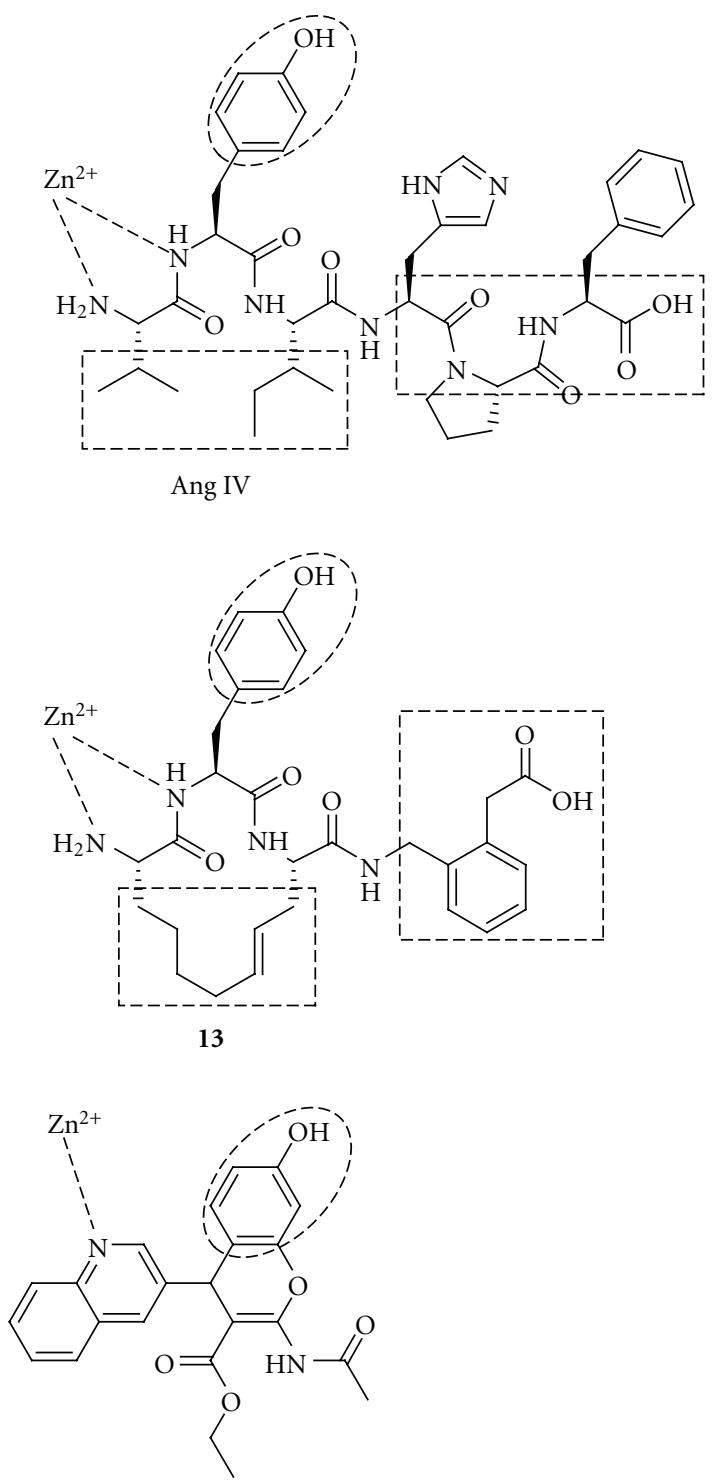

HFI-437

FIGURE 15: Ang IV, a peptidomimetic (13) and a non-peptidic (HFI437) IRAP inhibitor. The rectangles and circles show proposed recognition elements important for interaction with IRAP.

of IRAP. A series of drug-like small inhibitors with high potential for further optimization were identified by this process. The major challenge remaining for these inhibitors is to enable them to cross the blood-brain barrier.

\section{Acknowledgment}

This study was supported by the Swedish Research Council.

\section{References}

[1] A. J. Kastin, J. E. Zadina, R. D. Olson, and W. A. Banks, “The history of neuropeptide research: version 5.a," Annals of the New York Academy of Sciences, vol. 780, pp. 1-18, 1996.
[2] M. Hallberg and F. Nyberg, "Neuropeptide conversion to bioactive fragments - an important pathway in neuromodulation," Current Protein and Peptide Science, vol. 4, no. 1, pp. 31-44, 2003.

[3] S. Y. Chai, R. Fernando, S. Ye, G. R. Peck, and A. L. Albiston, "Insulin-regulated aminopeptidase, in Proteases in biology and disease," in Aminopeptidases in Biology and Disease, N. M. Hooper and U. Lendeckel, Eds., pp. 61-81, Kluwer Academic/Plenum Publishers, New York, NY, USA, 2004.

[4] M. Hallberg, P. Le Greves, and F. Nyberg, "Neuropeptide processing," in Proteases in Biology and Disease, Proteases in the Brain, U. Lendeckel and N. M. Hooper, Eds., pp. 203-234, Springer Science, New York, NY, USA, 2005.

[5] C. I. Johnston and J. Risvanis, "Preclinical pharmacology of angiotensin II receptor antagonists: update and outstanding issues," American Journal of Hypertension, vol. 10, no. 12, pp. 306S-310S, 1997.

[6] F. Fyhrquist and O. Saijonmaa, "Renin-angiotensin system revisited," Journal of Internal Medicine, vol. 264, no. 3, pp. 224-236, 2008.

[7] J. R. Blair-West, K. D. Carey, D. A. Denton, L. J. Madden, R. S. Weisinger, and R. E. Shade, "Possible contribution of brain angiotensin III to ingestive behaviors in baboons," American Journal of Physiology, vol. 281, no. 5, pp. R1633-R1636, 2001.

[8] J. W. Wright, A. V. Miller-Wing, M. J. Shaffer et al., "Angiotensin II(3-8) (ANG IV) hippocampal binding: potential role in the facilitation of memory," Brain Research Bulletin, vol. 32, no. 5, pp. 497-502, 1993.

[9] J. Lee, S. Y. Chai, F. A. O. Mendelsohn, M. J. Morris, and A. M. Allen, "Potentiation of cholinergic transmission in the rat hippocampus by angiotensin IV and LVV-hemorphin-7," Neuropharmacology, vol. 40, no. 4, pp. 618-623, 2001.

[10] M. Cesari, G. P. Rossi, and A. C. Pessina, "Biological properties of the angiotensin peptides other than angiotensin II: implications for hypertension and cardiovascular diseases," Journal of Hypertension, vol. 20, no. 5, pp. 793-799, 2002.

[11] K. L. Hall, S. Venkateswaran, J. M. Hanesworth, M. E. Schelling, and J. W. Harding, "Characterization of a functional angiotensin IV receptor on coronary microvascular endothelial cells," Regulatory Peptides, vol. 58, no. 3, pp. 107115, 1995.

[12] J. W. Wright and J. W. Harding, "Important roles for angiotensin III and IV in the brain renin-angiotensin system," Brain Research Reviews, vol. 25, no. 1, pp. 96-124, 1997.

[13] E. S. Pederson, R. Krishnan, J. W. Harding, and J. W. Wright, "A role for the angiotensin AT4 receptor subtype in overcoming scopolamine-induced spatial memory deficits," Regulatory Peptides, vol. 102, no. 2-3, pp. 147-156, 2001.

[14] D. De Bundel, I. Smolders, R. Yang, A. L. Albiston, Y. Michotte, and S. Y. Chai, "Angiotensin IV and LVV-haemorphin 7 enhance spatial working memory in rats: effects on hippocampal glucose levels and blood flow," Neurobiology of Learning and Memory, vol. 92, no. 1, pp. 19-26, 2009.

[15] R. Ardaillou and D. Chansel, "Synthesis and effects of active fragments of angiotensin II," Kidney International, vol. 52, no. 6, pp. 1458-1468, 1997.

[16] V. Jankowski, R. Vanholder, M. Van Der Giet et al., "Massspectrometric identification of a novel angiotensin peptide in human plasma," Arteriosclerosis, Thrombosis, and Vascular Biology, vol. 27, no. 2, pp. 297-302, 2007.

[17] R. Yang, I. Smolders, P. Vanderheyden et al., "Pressor and renal hemodynamic effects of the novel angiotensin 
a peptide are angiotensin II type 1A receptor dependent," Hypertension, vol. 57, no. 5, pp. 956-964, 2011.

[18] I. Banegas, I. Prieto, F. Vives et al., "Brain aminopeptidases and hypertension," Journal of the Renin-AngiotensinAldosterone System, vol. 7, no. 3, pp. 129-134, 2006.

[19] T. L. Reudelhuber, "The renin-angiotensin system: peptides and enzymes beyond angiotensin II," Current Opinion in Nephrology and Hypertension, vol. 14, no. 2, pp. 155-159, 2005.

[20] J. M. Saavedra, "Brain and pituitary angiotensin," Endocrine Reviews, vol. 13, no. 2, pp. 329-380, 1992.

[21] R. C. Speth, T. E. Brown, R. D. Barnes, and J. W. Wright, "Brain angiotensinergic activity: the state of our current knowledge," Proceedings of the Western Pharmacology Society, vol. 46, pp. 11-15, 2003.

[22] T. Unger, E. Badoer, D. Ganten, R. E. Lang, and R. Rettig, "Brain angiotensin: pathways and pharmacology," Circulation, vol. 77, no. 6, pp. I-40-I-54, 1988.

[23] C. I. Johnston, "Biochemistry and pharmacology of the renin-angiotensin system," Drugs, vol. 39, supplement 1, pp. 21-31, 1990.

[24] C. M. Ferrario and M. C. Chappell, "Novel angiotensin peptides," Cellular and Molecular Life Sciences, vol. 61, no. 21, pp. 2720-2727, 2004.

[25] G. Vauquelin, Y. Michotte, I. Smolders et al., "Cellular targets for angiotensin II fragments: pharmacological and molecular evidence," Journal of the Renin-Angiotensin-Aldosterone System, vol. 3, no. 4, pp. 195-204, 2002.

[26] S. V. B. Pinheiro, A. C. Simões e Silva, W. O. Sampaio et al., "Nonpeptide AVE 0991 is an angiotensin-(1-7) receptor mas agonist in the mouse kidney," Hypertension, vol. 44, no. 4, pp. 490-496, 2004.

[27] A. J. Ferreira, T. M. Murca, R. A. Fraga-Silva, C. H. Castro, M. K. Raizada, and R. A. Santos, "New cardiovascular and pulmonary therapeutic strategies based on the Angiotensinconverting enzyme 2/angiotensin-(1-7)/mas receptor axis," International Journal of Hypertension, vol. 2012, Article ID 147825, 2012.

[28] J. W. Wright, S. Mizutani, and J. W. Harding, "Focus on brain angiotensin III and aminopeptidase A in the control of hypertension," International Journal of Hypertension, vol. 2012, Article ID 124758, 2012.

[29] M. C. Khosla, R. A. Leese, W. L. Maloy, A. T. Ferreira, R. R. Smeby, and F. M. Bumpus, "Synthesis of some analogs of angiotensin II as specific antagonists of the parent hormone," Journal of Medicinal Chemistry, vol. 15, no. 8, pp. 792-795, 1972.

[30] E. Haber, "The role of renin in normal and pathological cardiovascular homeostasis," Circulation, vol. 54, no. 6, pp. 849-861, 1976.

[31] H. R. Brunner, H. Gavras, J. H. Laragh, and R. Keenan, "Angiotensin II blockade in man by SAR ALA angiotensin II for understanding and treatment of high blood pressure," Lancet, vol. 2, no. 7837, pp. 1045-1048, 1973.

[32] D. H. P. Streeten, G. H. Anderson Jr., and T. G. Dalakos, "Angiotensin blockade: its clinical significance," The American Journal of Medicine, vol. 60, no. 6, pp. 817-824, 1976.

[33] T. Ogihara, T. Yamamoto, and Y. Kumahara, "Clinical applications of synthetic angiotensin II analogue," Japanese Circulation Journal, vol. 38, no. 11, pp. 997-1003, 1974.

[34] M. A. Ondetti, B. Rubin, and D. W. Cushman, "Design of specific inhibitors of angiotensin converting enzyme: new class of orally active antihypertensive agents," Science, vol. 196, no. 4288, pp. 441-444, 1977.
[35] M. A. Ondetti and D. W. Cushman, "Inhibition of the renin-angiotensin system. A new approach to the therapy of hypertension," Journal of Medicinal Chemistry, vol. 24, no. 4, pp. 355-361, 1981.

[36] M. A. Ondetti and D. W. Cushman, "Inhibitors of angiotensin converting enzyme," in Biochemical Regulation of Blood Pressure, R. L. Soffer, Ed., pp. 165-204, Wiley, New York, NY, USA, 1981.

[37] P. A. Todd and R. C. Heel, "Enalapril. A review of its pharmacodynamic and pharmacokinetic properties, and therapeutic use in hypertension and congestive heart failure," Drugs, vol. 31, no. 3, pp. 198-248, 1986.

[38] P. A. Todd and K. L. Goa, "Enalapril. A reappraisal of its pharmacology and therapeutic use in hypertension," Drugs, vol. 43, no. 3, pp. 346-381, 1992.

[39] R. Natesh, S. L. U. Schwager, H. R. Evans, E. D. Sturrock, and K. R. Acharya, "Structural details on the binding of antihypertensive drugs captopril and enalaprilat to human testicular angiotensin I-converting enzyme," Biochemistry, vol. 43, no. 27, pp. 8718-8724, 2004.

[40] J. H. Bauer, "Angiotensin converting enzyme inhibitors," American Journal of Hypertension, vol. 3, no. 4, pp. 331-337, 1990.

[41] M. Azizi, R. Webb, J. Nussberger, and N. K. Hollenberg, "Renin inhibition with aliskiren: where are we now, and where are we going?” Journal of Hypertension, vol. 24, no. 2, pp. 243-256, 2006.

[42] M. M. Ibrahim, "RAS inhibition in hypertension," Journal of Human Hypertension, vol. 20, no. 2, pp. 101-108, 2006.

[43] C. Werner, M. Baumhäkel, K. K. Teo et al., "RAS blockade with ARB and ACE inhibitors: current perspective on rationale and patient selection," Clinical Research in Cardiology, vol. 97, no. 7, pp. 418-431, 2008.

[44] J. Maibaum, S. Stutz, R. Göschke et al., "Structural modification of the $\mathrm{P} 2$ ' position of 2,7-dialkyl-substituted 5(S)amino-4(S)-hydroxy-8-phenyl-octanecarboxamides: the discovery of aliskiren, a potent nonpeptide human renin inhibitor active after once daily dosing in marmosets," Journal of Medicinal Chemistry, vol. 50, no. 20, pp. 48324844, 2007.

[45] R. R. Wexler, W. J. Greenlee, J. D. Irvin et al., "Nonpeptide angiotensin II receptor antagonists: the next generation in antihypertensive therapy," Journal of Medicinal Chemistry, vol. 39, no. 3, pp. 625-656, 1996.

[46] C. A. Stoukides, H. J. McVoy, and A. F. Kaul, "Candesartan cilexetil: an angiotensin II receptor blocker," Annals of Pharmacotherapy, vol. 33, no. 12, pp. 1287-1298, 1999.

[47] C. H. Gleiter, C. Jägle, U. Gresser, and K. Mörike, "Candesartan," Cardiovascular Drug Reviews, vol. 22, no. 4, pp. 263284, 2004.

[48] S. E. Kjeldsen, J. Stlhammar, P. Hasvold, J. Bodegard, U. Olsson, and D. Russell, "Effects of losartan vs candesartan in reducing cardiovascular events in the primary treatment of hypertension," Journal of Human Hypertension, vol. 24, no. 4, pp. 263-273, 2010.

[49] M. Eklind-Cervenka, L. Benson, U. Dahlström, M. Edner, M. Rosenqvist, and L. H. Lund, "Association of candesartan vs losartan with all-cause mortality in patients with heart failure," Journal of the American Medical Association, vol. 305, no. 2, pp. 175-182, 2011.

[50] G. Vauquelin, F. Fierens, and I. V. Liefde, "Long-lasting angiotensin type 1 receptor binding and protection by candesartan: comparison with other biphenyl-tetrazole sartans," Journal of Hypertension, vol. 24, no. 1, pp. S23-S30, 2006. 
[51] R. A. Copeland, "The dynamics of drug-target interactions: drug-target residence time and its impact on efficacy and safety," Expert Opinion on Drug Discovery, vol. 5, no. 4, pp. 305-310, 2010.

[52] G. Vauquelin and S. J. Charlton, "Long-lasting target binding and rebinding as mechanisms to prolong in vivo drug action," British Journal of Pharmacology, vol. 161, no. 3, pp. 488-508, 2010.

[53] W. B. White, M. A. Weber, D. Sica et al., "Effects of the angiotensin receptor blocker azilsartan medoxomil versus olmesartan and valsartan on ambulatory and clinic blood pressure in patients with stages 1 and 2 hypertension," Hypertension, vol. 57, no. 3, pp. 413-420, 2011.

[54] G. L. Bakris, D. Sica, M. Weber et al., "The comparative effects of azilsartan medoxomil and olmesartan on ambulatory and clinic blood pressure," Journal of Clinical Hypertension, vol. 13, no. 2, pp. 81-88, 2011.

[55] P. Naik, P. Murumkar, R. Giridhar, and M. R. Yadav, "Angiotensin II receptor type 1 (AT1) selective nonpeptidic antagonists-a perspective," Bioorganic and Medicinal Chemistry, vol. 18, no. 24, pp. 8418-8456, 2010.

[56] B. Dahlöf, R. B. Devereux, S. E. Kjeldsen et al., "Cardiovascular morbidity and mortality in the Losartan Intervention for Endpoint reduction in hypertension study (LIFE): a randomised trial against atenolol," Lancet, vol. 359, no. 9311, pp. 995-1003, 2002.

[57] S. Julius, S. E. Kjeldsen, M. Weber et al., "Outcomes in hypertensive patients at high cardiovascular risk treated with regimens based on valsartan or amlodipine: the VALUE randomised trial," Lancet, vol. 363, no. 9426, pp. 2022-2031, 2004.

[58] R. Fogari, A. Mugellini, A. Zoppi et al., "Influence of losartan and atenolol on memory function in very elderly hypertensive patients," Journal of Human Hypertension, vol. 17, no. 11, pp. 781-785, 2003.

[59] L. Hansson, H. Lithell, I. Skoog et al., "Study on COgnition and Prognosis in the Elderly (SCOPE)," Blood Pressure, vol. 8, no. 3, pp. 177-183, 1999.

[60] P. Trenkwalder, "The Study on COgnition and Prognosis in the Elderly (SCOPE) - recent analyses," Journal of Hypertension, vol. 24, no. 1, pp. S107-S114, 2006.

[61] A. Zanchetti and D. Elmfeldt, "Findings and implications of the Study on COgnition and Prognosis in the Elderly (SCOPE) - a review," Blood Pressure, vol. 15, no. 2, pp. 7179, 2006.

[62] K. S. Kim, D. Abraham, B. Williams, J. D. Violin, L. Mao, and H. A. Rockman, "Beta-Arrestin-biased AT1R stimulation promotes cell survival during acute cardiac injury," American Journal of Physiology, vol. 303, pp. H1001-H1010, 2012.

[63] G. Boerrigter, D. G. Soergel, J. D. Violin, M. W. Lark, and J. C. Burnett Jr., "TRV120027, a novel beta-arrestin biased ligand at the angiotensin II type I receptor, unloads the heart and maintains renal function when added to furosemide in experimental heart failure," Circulation: Heart Failure, vol. 5, pp. 627-634, 2012.

[64] N. S. Kirkby, P. W. F. Hadoke, A. J. Bagnall, and D. J. Webb, "The endothelin system as a therapeutic target in cardiovascular disease: great expectations or bleak house?" British Journal of Pharmacology, vol. 153, no. 6, pp. 11051119, 2008.

[65] L. M. Ruilope, A. Dukat, M. Böhm, Y. Lacourcière, J. Gong, and M. P. Lefkowitz, "Blood-pressure reduction with LCZ696, a novel dual-acting inhibitor of the angiotensin II receptor and neprilysin: a randomised, double-blind, placebo-controlled, active comparator study," The Lancet, vol. 375, no. 9722, pp. 1255-1266, 2010.

[66] L. Paulis, U. M. Steckelings, and T. Unger, "Key advances in antihypertensive treatment," Nature Reviews Cardiology, vol. 9, pp. 276-285, 2011.

[67] L. Paulis and T. Unger, "Novel therapeutic targets for hypertension," Nature Reviews Cardiology, vol. 7, no. 8, pp. 431-441, 2010.

[68] N. Gallo-Payet, M. Shum, J. P. Baillargeon et al., "AT2 receptor agonists: exploiting the beneficial arm of ang II signaling," Current Hypertension Reviews, vol. 8, pp. 47-59, 2012.

[69] H. Yamada, M. Akishita, M. Ito et al., "AT2 receptor and vascular smooth muscle cell differentiation in vascular development," Hypertension, vol. 33, no. 6, pp. 1414-1419, 1999.

[70] Z. Lenkei, M. Palkovits, P. Corvol, and C. Llorens-Cortès, "Expression of angiotensin type-1 (AT1) and type-2 (AT2) receptor mRNAs in the adult rat brain: a functional neuroanatomical review," Frontiers in Neuroendocrinology, vol. 18, no. 4, pp. 383-439, 1997.

[71] M. Horiuchi, M. Mogi, and M. Iwai, "The angiotensin II type 2 receptor in the brain," Journal of the Renin-AngiotensinAldosterone System, vol. 11, no. 1, pp. 1-6, 2010.

[72] T. Ichiki, P. A. Labosky, C. Shiota et al., "Effects on blood pressure exploratory behaviour of mice lacking angiotensin II type 2 receptor," Nature, vol. 377, no. 6551, pp. 748-750, 1995.

[73] C. Tebbs, M. K. Pratten, and F. B. Pipkin, "Angiotensin II is a growth factor in the peri-implantation rat embryo," Journal of Anatomy, vol. 195, no. 1, pp. 75-86, 1999.

[74] M. A. Millan, D. M. Jacobowitz, G. Aguilera, and K. J. Catt, "Differential distribution of AT1 and AT2 angiotensin II receptor subtypes in the rat brain during development," Proceedings of the National Academy of Sciences of the United States of America, vol. 88, no. 24, pp. 11440-11444, 1991.

[75] K. Tsutsumi and J. M. Saavedra, "Characterization and development of angiotensin II receptor subtypes (AT1 and AT2) in rat brain," American Journal of Physiology, vol. 261, no. 1, pp. R209-R216, 1991.

[76] Z. Lenkei, M. Palkovits, P. Corvol, and C. Llorens-Cortes, "Distribution of angiotensin II type-2 receptor (AT2) mRNA expression in the adult rat brain," The Journal of Comparative Neurology, vol. 373, pp. 322-339, 1996.

[77] T. N. Grammatopoulos, S. M. Jones, F. A. Ahmadi et al., "Angiotensin type I receptor antagonist losartan, reduces MPTP-induced degeneration of dopaminergic neurons in substantia nigra," Molecular Neurodegeneration, vol. 2, no. 1, article 1, 2007.

[78] G. A. Argañaraz, A. C. Konno, S. R. Perosa et al., "The renin-angiotensin system is upregulated in the cortex and hippocampus of patients with temporal lobe epilepsy related to mesial temporal sclerosis," Epilepsia, vol. 49, no. 8, pp. 1348-1357, 2008.

[79] S. Abdalla, H. Lother, A. El Missiry et al., "Angiotensin II AT2 receptor oligomers mediate G-protein dysfunction in an animal model of Alzheimer disease," Journal of Biological Chemistry, vol. 284, no. 10, pp. 6554-6565, 2009.

[80] N. Gallo-Payet, M. O. Guimond, L. Bilodeau, C. Wallinder, M. Alterman, and A. Hallberg, "Angiotensin II, a neuropeptide at the frontier between endocrinology and neuroscience: is there a link between the angiotensin II type 2 receptor and Alzheimer's disease?" Front Endocrinology, vol. 2, article 17, 2011. 
[81] F. Jing, M. Mogi, A. Sakata et al., "Direct stimulation of angiotensin II type 2 receptor enhances spatial memory," Journal of Cerebral Blood Flow \& Metabolism, vol. 32, pp. 248 255, 2012.

[82] S. Meffert, M. Stoll, U. M. Steckelings, S. P. Bottari, and T. Unger, "The angiotensin II AT2 receptor inhibits proliferation and promotes differentiation in PC12W cells," Molecular and Cellular Endocrinology, vol. 122, no. 1, pp. 59-67, 1996.

[83] L. Laflamme, M. De Gasparo, J. M. Gallo, M. D. Payet, and N. Gallo-Payet, "Angiotensin II induction of neurite outgrowth by AT2 receptors in NG108-15 cells. Effect counteracted by the AT1 receptors," Journal of Biological Chemistry, vol. 271, no. 37, pp. 22729-22735, 1996.

[84] R. Lucius, S. Gallinat, P. Rosenstiel, T. Herdegen, J. Sievers, and T. Unger, "The angiotensin II type 2 (AT2) receptor promotes axonal regeneration in the optic nerve of adult rats," Journal of Experimental Medicine, vol. 188, no. 4, pp. 661-670, 1998.

[85] M. De Gasparo, K. J. Catt, T. Inagami, J. W. Wright, and T. Unger, "International union of pharmacology. XXIII. The angiotensin II receptors," Pharmacological Reviews, vol. 52, no. 3, pp. 415-472, 2000.

[86] R. M. Carey, Z. Q. Wang, and H. M. Siragy, "Role of the angiotensin type 2 receptor in the regulation of blood pressure and renal function," Hypertension, vol. 35, no. 1, pp. 155-163, 2000.

[87] U. M. Steckelings, F. Rompe, E. Kaschina et al., "The past, present and future of angiotensin II type 2 receptor stimulation," Journal of the Renin-Angiotensin-Aldosterone System, vol. 11, no. 1, pp. 67-73, 2010.

[88] R. M. Carey, "Angiotensin type-2 receptors and cardiovascular function: are angiotensin type-2 receptors protective?" Current Opinion in Cardiology, vol. 20, no. 4, pp. 264-269, 2005.

[89] C. Savoia, R. M. Touyz, M. Volpe, and E. L. Schiffrin, "Angiotensin type 2 receptor in resistance arteries of type 2 diabetic hypertensive patients," Hypertension, vol. 49, no. 2, pp. 341-346, 2007.

[90] H. M. Siragy, "The angiotensin II type 2 receptor and the kidney," Journal of the Renin-Angiotensin-Aldosterone System, vol. 11, no. 1, pp. 33-36, 2010.

[91] T. Unger, "Targeting cardiovascular protection: the concept of dual renin-angiotensin system control," MedGenMed Medscape General Medicine, vol. 10, article S4, 2008.

[92] C. A. Lemarié and E. L. Schiffrin, "The angiotensin II type 2 receptor in cardiovascular disease," Journal of the ReninAngiotensin-Aldosterone System, vol. 11, no. 1, pp. 19-31, 2010.

[93] U. M. Steckelings, E. Kaschina, and T. Unger, "The AT2 receptor-a matter of love and hate," Peptides, vol. 26, no. 8, pp. 1401-1409, 2005.

[94] Y. Wan, C. Wallinder, B. Plouffe et al., "Design, synthesis, and biological evaluation, of the first selective nonpeptide AT2 receptor agonist," Journal of Medicinal Chemistry, vol. 47, no. 24, pp. 5995-6008, 2004.

[95] X. Wu, Y. Wan, A. K. Mahalingam et al., "Selective angiotensin II AT2 receptor agonists: arylbenzylimidazole structure-activity relationships," Journal of Medicinal Chemistry, vol. 49, no. 24, pp. 7160-7168, 2006.

[96] A. M. S. Murugaiah, C. Wallinder, A. K. Mahalingam et al., "Selective angiotensin II AT2 receptor agonists devoid of the imidazole ring system," Bioorganic and Medicinal Chemistry, vol. 15, no. 22, pp. 7166-7183, 2007.
[97] S. D. Kivlighn, W. R. Huckle, G. J. Zingaro et al., "Discovery of L-162,313: a nonpeptide that mimics the biological actions of angiotensin II," American Journal of Physiology, vol. 268, no. 3, pp. R820-R823, 1995.

[98] B. Mertens, P. Vanderheyden, Y. Michotte, and S. Sarre, "Direct angiotensin II type 2 receptor stimulation decreases dopamine synthesis in the rat striatum," Neuropharmacology, vol. 58, no. 7, pp. 1038-1044, 2010.

[99] M. Mogi and M. Horiuchi, "Effect of angiotensin II type 2 receptor on stroke, cognitive impairment and neurodegenerative diseases," Geriatric Gerontology. In press.

[100] E. Kaschina, A. Grzesiak, J. Li et al., "Angiotensin II type 2 receptor stimulation: a novel option of therapeutic interference with the renin-angiotensin system in myocardial infarction?" Circulation, vol. 118, no. 24, pp. 2523-2532, 2008.

[101] F. Rompe, M. Artuc, A. Hallberg et al., "Direct angiotensin II type 2 receptor stimulation acts anti-inflammatory through epoxyeicosatrienoic acid and inhibition of nuclear factor $\kappa \mathrm{b}$," Hypertension, vol. 55, no. 4, pp. 924-931, 2010.

[102] A. Rehman, A. Leibowitz, N. Yamamoto et al., "Angiotensin type 2 receptor agonist compound 21 reduces vascular injury and myocardial fibrosis in stroke-prone spontaneously hypertensive rats," Hypertension, vol. 59, pp. 291-299, 2012.

[103] S. Foulquier, U. M. Steckelings, and T. Unger, "Impact of the AT(2) receptor agonist C21 on blood pressure and beyond," Current Hypertension Reports, vol. 14, no. 5, pp. 403-409, 2012.

[104] N. Shraim, B. Mertens, R. Clinckers, S. Sarre, Y. Michotte, and A. Van Eeckhaut, "Microbore liquid chromatography with UV detection to study the in vivo passage of compound 21, a non-peptidergic AT2 receptor agonist, to the striatum in rats," Journal of Neuroscience Methods, vol. 202, pp. 137-142, 2011.

[105] "Spinifex EMA401 meets primary endpoint in phase 2 trail," in Pharmaceutical Business Review, Progressive Media Group, London, UK, 2012.

[106] J. J. Braszko, G. Kupryszewski, B. Witczuk, and K. Wisniewski, "Angiotensin II-(3-8)-hexapeptide affects motor activity, performance of passive avoidance and a conditioned avoidance response in rats," Neuroscience, vol. 27, no. 3, pp. 777-783, 1988.

[107] J. Lee, A. L. Albiston, A. M. Allen et al., "Effect of I.C.V. injection of AT4 receptor ligands, NLE 1-angiotensin IV and LVV-hemorphin 7, on spatial learning in rats," Neuroscience, vol. 124, no. 2, pp. 341-349, 2004.

[108] J. W. Wright, J. A. Clemens, J. A. Panetta et al., "Effects of LY231617 and angiotensin IV on ischemia-induced deficits in circular water maze and passive avoidance performance in rats," Brain Research, vol. 717, no. 1-2, pp. 1-11, 1996.

[109] J. W. Wright, L. Stubley, E. S. Pederson, E. A. Kramár, J. M. Hanesworth, and J. W. Harding, "Contributions of the brain angiotensin IV-AT4 receptor subtype system to spatial learning," Journal of Neuroscience, vol. 19, no. 10, pp. 39523961, 1999.

[110] J. J. Braszko, P. Wielgat, and A. Walesiuk, "Effect of D3 dopamine receptors blockade on the cognitive effects of angiotensin IV in rats," Neuropeptides, vol. 42, no. 3, pp. 301309, 2008.

[111] J. Lee, T. Mustafa, S. G. McDowall et al., "Structure-activity study of LVV-hemorphin-7: angiotensin AT4 receptor ligand and inhibitor of insulin-regulated aminopeptidase," Journal of Pharmacology and Experimental Therapeutics, vol. 305, no. 1, pp. 205-211, 2003. 
[112] S. Y. Chai, H. R. Yeatman, M. W. Parker et al., "Development of cognitive enhancers based on inhibition of insulinregulated aminopeptidase," BMC Neuroscience, vol. 9, no. 2, article S14, 2008.

[113] A. L. Albiston, S. Diwakarla, R. N. Fernando et al., "Identification and development of specific inhibitors for insulin-regulated aminopeptidase as a new class of cognitive enhancers," British Journal of Pharmacology, vol. 164, no. 1, pp. 37-47, 2011.

[114] J. W. Wright and J. W. Harding, "Brain renin-angiotensin-A new look at an old system," Progress in Neurobiology, vol. 95, no. 1, pp. 49-67, 2011.

[115] J. Birks, "Cholinesterase inhibitors for Alzheimer's disease," Cochrane Database of Systematic Reviews, no. 1, Article ID CD005593, 2006.

[116] K. M. Cosman, L. L. Boyle, and A. P. Porsteinsson, "Memantine in the treatment of mild-to-moderate Alzheimer's disease," Expert Opinion on Pharmacotherapy, vol. 8, no. 2, pp. 203-214, 2007.

[117] P. M. Doraiswamy and G. L. Xiong, "Pharmacological strategies for the prevention of Alzheimer's disease," Expert Opinion on Pharmacotherapy, vol. 7, no. 1, pp. 1-10, 2006.

[118] P. Raina, P. Santaguida, A. Ismaila et al., "Effectiveness of cholinesterase inhibitors and memantine for treating dementia: evidence review for a clinical practice guideline," Annals of Internal Medicine, vol. 148, no. 5, pp. 379-397, 2008.

[119] G. N. Swanson, J. M. Hanesworth, M. F. Sardinia et al., "Discovery of a distinct binding site for angiotensin II (3-8), a putative angiotensin IV receptor," Regulatory Peptides, vol. 40, no. 3, pp. 409-419, 1992.

[120] J. W. Harding, V. I. Cook, A. V. Miller-Wing et al., "Identification of an AII (3-8) [AIV] binding site in guinea pig hippocampus," Brain Research, vol. 583, no. 1-2, pp. 340-343, 1992.

[121] M. De Gasparo, A. Husain, W. Alexander et al., "Proposed update of angiotensin receptor nomenclature," Hypertension, vol. 25, no. 5, pp. 924-927, 1995.

[122] M. F. Sardinia, J. M. Hanesworth, L. T. Krebs, and J. W. Harding, "AT4 receptor binding characteristics: D-Amino acid- and glycine-substituted peptides," Peptides, vol. 14, no. 5, pp. 949-954, 1993.

[123] M. F. Sardinia, "AT4 receptor Structure-Binding relationship: $\mathrm{N}$-terminal-modified angiotensin IV analogues," Peptides, vol. 15, no. 8, pp. 1399-1406, 1994.

[124] R. Krishnan, J. M. Hanesworth, J. W. Wright, and J. W. Harding, "Structure-binding studies of the adrenal AT4 receptor: analysis of position two- and three-modified angiotensin IV analogs," Peptides, vol. 20, no. 8, pp. 915-920, 1999.

[125] L. T. Krebs, E. A. Kramár, J. M. Hanesworth et al., "Characterization of the binding properties and physiological action of divalinal-angiotensin IV, a putative AT4 receptor antagonist," Regulatory Peptides, vol. 67, no. 2, pp. 123-130, 1996.

[126] E. A. Kramár, D. L. Armstrong, S. Ikeda, M. J. Wayner, J. W. Harding, and J. W. Wright, "The effects of angiotensin IV analogs on long-term potentiation within the CA1 region of the hippocampus in vitro," Brain Research, vol. 897, no. 1-2, pp. 114-121, 2001.

[127] T. Kobori, K. Goda, K. Sugimoto, T. Ota, and K. Tomisawa, "Preparation of peptide derivatives as angiotensin IV receptor agonists," 1997, WO 97/03093 A1.

[128] T. Kobori, K. Goda, K. Sugimoto, T. Ota, and K. Tomisawa, "Preparation of amino acid derivatives as angiotensin IV receptor agonists," 1998, WO 98/05624 A1.
[129] A. L. Albiston, S. G. McDowall, D. Matsacos et al., "Evidence that the angiotensin IV (AT4) receptor is the enzyme insulinregulated aminopeptidase," Journal of Biological Chemistry, vol. 276, no. 52, pp. 48623-48626, 2001.

[130] M. S. Wolfe, "Therapeutic strategies for Alzheimer's disease," Nature Reviews Drug Discovery, vol. 1, no. 11, pp. 859-866, 2002.

[131] M. Hallberg, "Targeting the insulin-regulated aminopeptidase/AT4 receptor for cognitive disorders," Drug News and Perspectives, vol. 22, no. 3, pp. 133-139, 2009.

[132] P. R. Gard, "Cognitive-enhancing effects of angiotensin IV," BMC Neuroscience, vol. 9, no. 2, article S15, 2008.

[133] J. W. Wright and J. W. Harding, "The angiotensin AT4 receptor subtype as a target for the treatment of memory dysfunction associated with Alzheimer's disease," Journal of the Renin-Angiotensin-Aldosterone System, vol. 9, no. 4, pp. 226-237, 2008.

[134] D. De Bundel, I. Smolders, P. Vanderheyden, and Y. Michotte, "Ang II and Ang IV: unraveling the mechanism of action on synaptic plasticity, memory, and epilepsy," CNS Neuroscience and Therapeutics, vol. 14, no. 4, pp. 315-339, 2008.

[135] M. Tsujimoto, S. Mizutani, H. Adachi, M. Kimura, H. Nakazato, and Y. Tomoda, "Identification of human placental leucine aminopeptidase as oxytocinase," Archives of Biochemistry and Biophysics, vol. 292, no. 2, pp. 388-392, 1992.

[136] T. Rogi, M. Tsujimoto, H. Nakazato, S. Mizutani, and Y. Tomoda, "Human placental leucine aminopeptidase/oxytocinase: a new member of type II membrane-spanning zinc metallopeptidase family," Journal of Biological Chemistry, vol. 271, no. 1, pp. 56-61, 1996.

[137] T. E. Rasmussen, S. Pedraza-Diaz, R. Hardre, P. G. Laustsen, A. G. Carrion, and T. Kristensen, "Structure of the human oxytocinase/insulin-regulated aminopeptidase gene and localization to chromosome 5q21," European Journal of Biochemistry, vol. 267, no. 8, pp. 2297-2306, 2000.

[138] S. R. Keller, H. M. Scott, C. C. Mastick, R. Aebersold, and G. E. Lienhard, "Cloning and characterization of a novel insulin-regulated membrane aminopeptidase from Glut4 vesicles," Journal of Biological Chemistry, vol. 270, no. 40, pp. 23612-23618, 1995.

[139] P. G. Laustsen, S. Vang, and T. Kristensen, "Mutational analysis of the active site of human insulin-regulated aminopeptidase," European Journal of Biochemistry, vol. 268, no. 1, pp. 98-104, 2001.

[140] P. G. Laustsen, T. E. Rasmussen, K. Petersen et al., “The complete amino acid sequence of human placental oxytocinase," Biochimica et Biophysica Acta, vol. 1352, no. 1, pp. 1-7, 1997.

[141] A. L. Albiston, G. R. Peck, H. R. Yeatman, R. Fernando, S. Ye, and S. Y. Chai, "Therapeutic targeting of insulinregulated aminopeptidase: heads and tails?" Pharmacology and Therapeutics, vol. 116, no. 3, pp. 417-427, 2007.

[142] K. Ito, Y. Nakajima, Y. Onohara et al., "Crystal structure of aminopeptidase N (Proteobacteria alanyl aminopeptidase) from Escherichia coli and conformational change of methionine 260 involved in substrate recognition," Journal of Biological Chemistry, vol. 281, no. 44, pp. 33664-33676, 2006.

[143] F. Tholander, A. Muroya, B. P. Roques, M. C. FourniéZaluski, M. M. G. M. Thunnissen, and J. Z. Haeggström, "Structure-based dissection of the active site chemistry of leukotriene A4 hydrolase: implications for M1 aminopeptidases and inhibitor design," Chemistry and Biology, vol. 15, no. 9, pp. 920-929, 2008.

[144] N. Luciani, C. Marie-Claire, E. Ruffet, A. Beaumont, B. P. Roques, and M. C. Fournié-Zaluski, "Characterization of 
Glu350 as a critical residue involved in the $\mathrm{N}$-terminal amine binding site of aminopeptidase N (EC 3.4.11.2): insights into its mechanism of action," Biochemistry, vol. 37, no. 2, pp. 686-692, 1998.

[145] S. Ye, S. Y. Chai, R. A. Lew, and A. L. Albiston, "Insulinregulated aminopeptidase: analysis of peptide substrate and inhibitor binding to the catalytic domain," Biological Chemistry, vol. 388, no. 4, pp. 399-403, 2007.

[146] S. Ye, S. Y. Chai, R. A. Lew et al., "Identification of modulating residues defining the catalytic cleft of insulin-regulated aminopeptidase," Biochemistry and Cell Biology, vol. 86, no. 3, pp. 251-261, 2008.

[147] H. Matsumoto, T. Rogi, K. Yamashiro et al., "Characterization of a recombinant soluble form of human placental leucine aminopeptidase/oxytocinase expressed in Chinese hamster ovary cells," European Journal of Biochemistry, vol. 267, no. 1, pp. 46-52, 2000.

[148] M. G. Wallis, M. F. Lankford, and S. R. Keller, "Vasopressin is a physiological substrate for the insulin-regulated aminopeptidase IRAP," American Journal of Physiology, vol. 293, no. 4, pp. E1092-E1102, 2007.

[149] A. L. Albiston, T. Mustafa, S. G. McDowall, F. A. O. Mendelsohn, J. Lee, and S. Y. Chai, "AT4 receptor is insulinregulated membrane aminopeptidase: potential mechanisms of memory enhancement," Trends in Endocrinology and Metabolism, vol. 14, no. 2, pp. 72-77, 2003.

[150] S. Y. Chai, R. Fernando, G. Peck et al., "The angiotensin IV/AT4 receptor," Cellular and Molecular Life Sciences, vol. 61, no. 21, pp. 2728-2737, 2004.

[151] G. L. Kovacs and D. De Wied, "Peptidergic modulation of learning and memory processes," Pharmacological Reviews, vol. 46, no. 3, pp. 269-291, 1994.

[152] B. Alescio-Lautier, V. Paban, and B. Soumireu-Mourat, "Neuromodulation of memory in the hippocampus by vasopressin," European Journal of Pharmacology, vol. 405, no. 1-3, pp. 63-72, 2000.

[153] M. A. Gulpinar and B. C. Yegen, "The physiology of learning and memory: role of peptides and stress," Current Protein \& Peptide Science, vol. 5, pp. 457-473, 2004.

[154] A. L. Albiston, R. N. Fernando, H. R. Yeatman et al., "Gene knockout of insulin-regulated aminopeptidase: loss of the specific binding site for angiotensin IV and age-related deficit in spatial memory," Neurobiology of Learning and Memory, vol. 93, no. 1, pp. 19-30, 2010.

[155] E. B. Einstein, C. A. Patterson, B. J. Hon et al., "Somatostatin signaling in neuronal cilia is critical for object recognition memory," Journal of Neuroscience, vol. 30, no. 12, pp. 4306$4314,2010$.

[156] R. N. Fernando, A. L. Albiston, and S. Y. Chai, "The insulinregulated aminopeptidase IRAP is colocalised with GLUT4 in the mouse hippocampus - potential role in modulation of glucose uptake in neurones?" European Journal of Neuroscience, vol. 28, no. 3, pp. 588-598, 2008.

[157] P. M. L. Vanderheyden, "From angiotensin IV binding site to AT4 receptor," Molecular and Cellular Endocrinology, vol. 302, no. 2, pp. 159-166, 2009.

[158] I. Garreau, D. Chansel, S. Vandermeersch, I. Fruitier, J. M. Piot, and R. Ardaillou, "Hemorphins inhibit angiotensin IV binding and interact with aminopeptidase N," Peptides, vol. 19, no. 8, pp. 1339-1348, 1998.

[159] H. Demaegdt, P. J. Lenaerts, J. Swales et al., "Angiotensin AT4 receptor ligand interaction with cystinyl aminopeptidase and aminopeptidase N: [125I]Angiotensin IV only binds to the cystinyl aminopeptidase apo-enzyme," European Journal of Pharmacology, vol. 546, no. 1-3, pp. 19-27, 2006.

[160] J. W. Wright, B. J. Yamamoto, and J. W. Harding, "Angiotensin receptor subtype mediated physiologies and behaviors: new discoveries and clinical targets," Progress in Neurobiology, vol. 84, no. 2, pp. 157-181, 2008.

[161] B. J. Yamamoto, P. D. Elias, J. A. Masino et al., "The angiotensin IV analog Nle-Tyr-Leu- $\psi-(\mathrm{CH} 2-\mathrm{NH} 2) 3-4-\mathrm{His}-$ Pro-Phe (Norleual) can act as a hepatocyte growth factor/cmet inhibitor," Journal of Pharmacology and Experimental Therapeutics, vol. 333, no. 1, pp. 161-173, 2010.

[162] J. W. Wright and J. W. Harding, "The brain angiotensin IV/AT4 receptor system as a new target for the treatment of Alzheimer's disease," Drug Development Research, vol. 70, no. 7, pp. 472-480, 2009.

[163] A. McCoy, Pharmacokinetic characterization of angiotensin IV analogs with therapeutic potential for cancer and dementia [thesis from Department of Veterinary and Comparative Anatomy, Pharmacology, and Physiology], Washington State University, Washington, DC, USA, 2010.

[164] R. A. Lew, T. Mustafa, S. Ye, S. G. McDowall, S. Y. Chai, and A. L. Albiston, "Angiotensin AT4 ligands are potent, competitive inhibitors of insulin regulated aminopeptidase (IRAP)," Journal of Neurochemistry, vol. 86, no. 2, pp. 344350, 2003.

[165] H. Demaegdt, H. Laeremans, J. P. De Backer et al., "Synergistic modulation of cystinyl aminopeptidase by divalent cation chelators," Biochemical Pharmacology, vol. 68, no. 5, pp. 893900, 2004.

[166] H. Laeremans, H. Demaegdt, J. P. De Backer et al., "Metal ion modulation of cystinyl aminopeptidase," Biochemical Journal, vol. 390, no. 1, pp. 351-357, 2005.

[167] H. Demaegdt, A. Lukaszuk, E. De Buyser et al., "Selective labeling of IRAP by the tritiated AT4 receptor ligand $[3 \mathrm{H}]$ Angiotensin IV and its stable analog [3H]AL-11," Molecular and Cellular Endocrinology, vol. 311, no. 1-2, pp. 77-86, 2009.

[168] A. Lukaszuk, H. Demaegdt, E. Szemenyei et al., " $\beta$-homoamino acid scan of angiotensin IV," Journal of Medicinal Chemistry, vol. 51, no. 7, pp. 2291-2296, 2008.

[169] R. Yang, I. Smolders, D. De Bundel et al., "Brain and peripheral angiotensin II type 1 receptors mediate renal vasoconstrictor and blood pressure responses to angiotensin IV in the rat," Journal of Hypertension, vol. 26, no. 5, pp. 9981007, 2008.

[170] A. Lukaszuk, H. Demaegdt, D. Feytens, P. Vanderheyden, G. Vauquelin, and D. Tourwé, "The replacement of His(4) in angiotensin IV by conformationally constrained residues provides highly potent and selective analogues," Journal of Medicinal Chemistry, vol. 52, no. 18, pp. 5612-5618, 2009.

[171] H. Chen, B. P. Roques, and M. C. Fournié-Zaluski, "Design of the first highly potent and selective aminopeptidase $\mathrm{N}$ (EC 3.4.11.2) inhibitor," Bioorganic and Medicinal Chemistry Letters, vol. 9, no. 11, pp. 1511-1516, 1999.

[172] H. Demaegdt, J. P. De Backer, A. Lukaszuk et al., "Angiotensin IV displays only low affinity for native insulin-regulated aminopeptidase (IRAP)," Fundamental and Clinical Pharmacology, vol. 26, pp. 194-197, 2012.

[173] H. Demaegdt, L. Smitz, J. P. De Backer et al., "Translocation of the insulin-regulated aminopeptidase to the cell surface: detection by radioligand binding," British Journal of Pharmacology, vol. 154, no. 4, pp. 872-881, 2008.

[174] A. Axén, H. Andersson, G. Lindeberg et al., "Small potent ligands to the insulin-regulated aminopeptidase (IRAP)/AT4 
receptor," Journal of Peptide Science, vol. 13, no. 7, pp. 434444, 2007.

[175] D. B. Ascher, B. A. Cromer, C. J. Morton et al., "Regulation of insulin-regulated membrane aminopeptidase activity by its C-terminal domain," Biochemistry, vol. 50, no. 13, pp. 2611$2622,2011$.

[176] A. Lukaszuk, H. Demaegdt, I. van den Eynde, P. Vanderheyden, G. Vauquelin, and D. Tourwé, "Conformational constraints in angiotensin IV to probe the role of Tyr2, Pro5 and Phe6," Journal of Peptide Science, vol. 17, no. 8, pp. 545$553,2011$.

[177] H. Andersson, H. Demaegdt, G. Vauquelin, G. Lindeberg, A. Karlén, and M. Hallberg, "Ligands to the (IRAP)/AT4 receptor encompassing a 4-hydroxydiphenylmethane scaffold replacing Tyr2," Bioorganic and Medicinal Chemistry, vol. 16, no. 14, pp. 6924-6935, 2008.

[178] A. Axén, G. Lindeberg, H. Demaegdt, G. Vauquelin, A. Karlén, and M. Hallberg, "Cyclic insulin-regulated aminopeptidase (IRAP)/AT4 receptor ligands," Journal of Peptide Science, vol. 12, no. 11, pp. 705-713, 2006.

[179] H. Andersson, H. Demaegdt, A. Johnsson et al., "Potent macrocyclic inhibitors of insulin-regulated aminopeptidase (IRAP) by olefin ring-closing metathesis," Journal of Medicinal Chemistry, vol. 54, no. 11, pp. 3779-3792, 2011.

[180] H. Andersson, H. Demaegdt, G. Vauquelin et al., "Disulfide cyclized tripeptide analogues of angiotensin IV as potent and selective inhibitors of insulin-regulated aminopeptidase (IRAP)," Journal of Medicinal Chemistry, vol. 53, no. 22, pp. 8059-8071, 2010.

[181] B. Schmidt, S. Lindman, W. Tong et al., "Design, synthesis, and biological activities of four angiotensin II receptor ligands with $\gamma$-turn mimetics replacing amino acid residues 3-5," Journal of Medicinal Chemistry, vol. 40, no. 6, pp. 903 919, 1997.

[182] S. Lindman, G. Lindeberg, A. Gogoll, F. Nyberg, A. Karlén, and A. Hallberg, "Synthesis, receptor binding affinities and conformational properties of cyclic methylenedithioether analogues of angiotensin II," Bioorganic and Medicinal Chemistry, vol. 9, no. 3, pp. 763-772, 2001.

[183] E. Marsault and M. L. Peterson, "Macrocycles are great cycles: applications, opportunities, and challenges of synthetic macrocycles in drug discovery," Journal of Medicinal Chemistry, vol. 54, no. 7, pp. 1961-2004, 2011.

[184] E. M. Driggers, S. P. Hale, J. Lee, and N. K. Terrett, "The exploration of macrocycles for drug discovery-An underexploited structural class," Nature Reviews Drug Discovery, vol. 7, no. 7, pp. 608-624, 2008.

[185] M. M. G. M. Thunnissen, P. Nordlund, and J. Z. Haeggström, "Crystal structure of human leukotriene A4 hydrolase, a bifunctional enzyme in inflammation," Nature Structural Biology, vol. 8, no. 2, pp. 131-135, 2001.

[186] A. L. Albiston, C. J. Morton, L. N. Hooi et al., "Identification and characterization of a new cognitive enhancer based on inhibition of insulin-regulated aminopeptidase," FASEB Journal, vol. 22, no. 12, pp. 4209-4217, 2008.

[187] A. L. Albiston, V. Pham, S. Ye et al., "Phenylalanine-544 plays a key role in substrate and inhibitor binding by providing a hydrophobic packing point at the active site of insulinregulated aminopeptidase," Molecular Pharmacology, vol. 78, no. 4, pp. 600-607, 2010. 


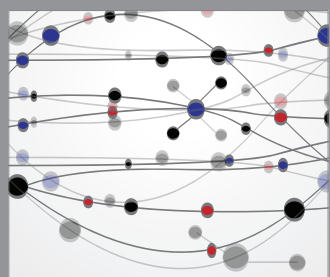

The Scientific World Journal
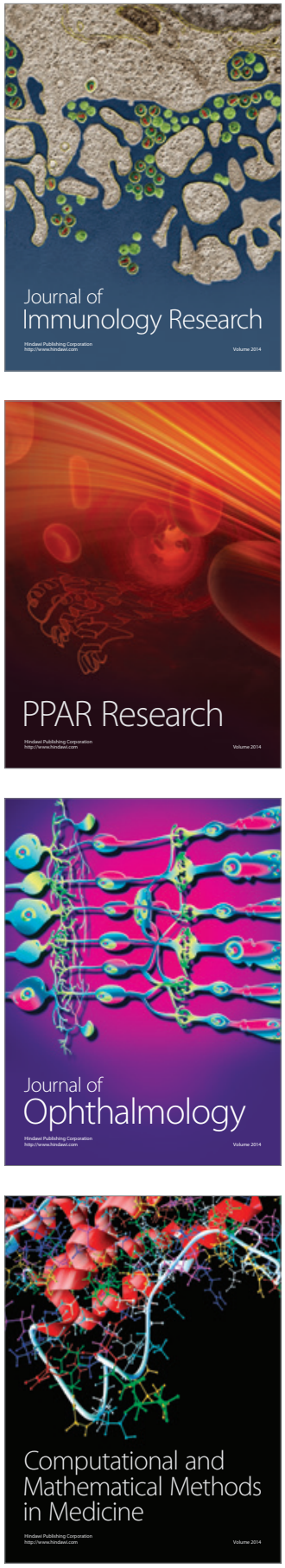

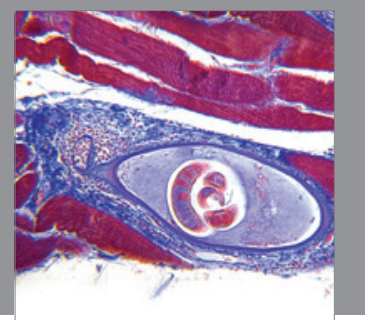

Gastroenterology

Research and Practice
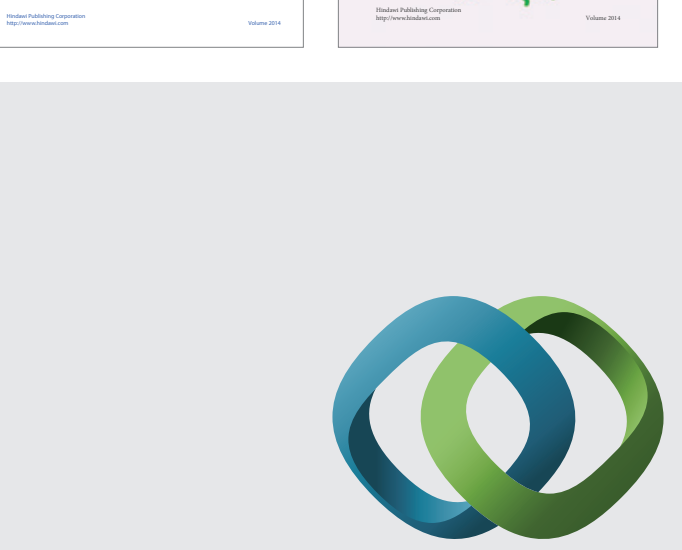

\section{Hindawi}

Submit your manuscripts at

http://www.hindawi.com
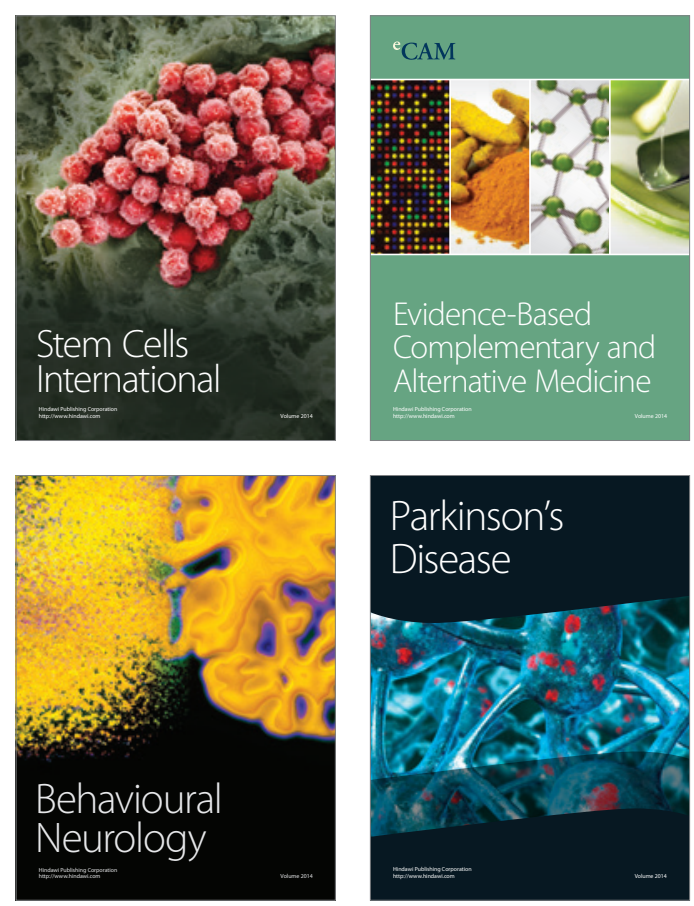

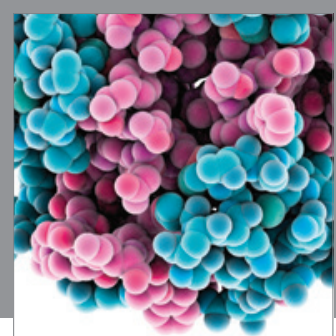

Journal of
Diabetes Research

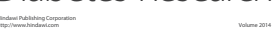

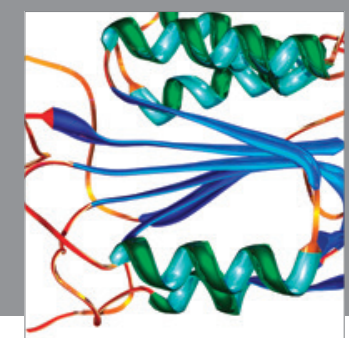

Disease Markers
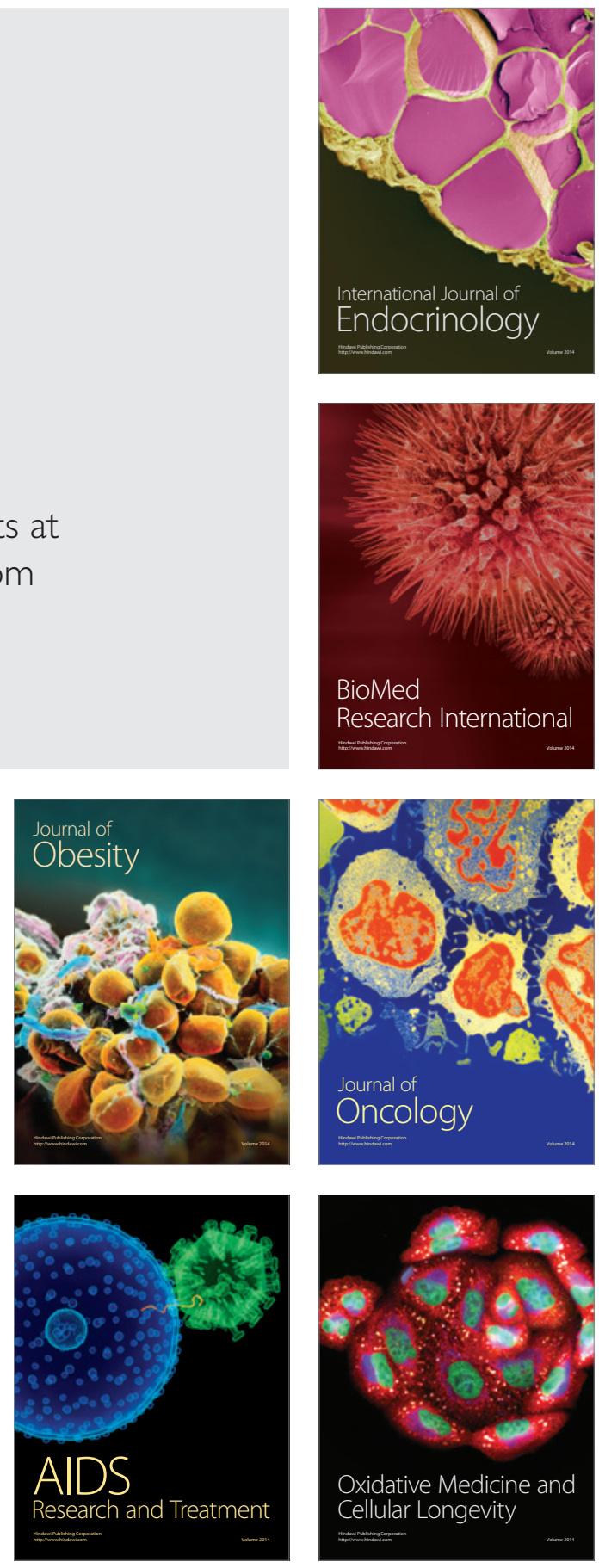